\title{
Recognizing and tracking volcanic hazards related to non-magmatic unrest: a review
}

\author{
Dmitri Rouwet ${ }^{1 *}$, Laura Sandri ${ }^{1}$, Warner Marzocchi ${ }^{2}$, Joachim Gottsmann ${ }^{3}$, Jacopo Selva ${ }^{1}$, Roberto Tonini ${ }^{2}$ \\ and Paolo Papale ${ }^{4}$
}

\begin{abstract}
Eruption forecasting is a major goal in volcanology. Logically, but unfortunately, forecasting hazards related to non-magmatic unrest is too often overshadowed by eruption forecasting, although many volcanoes often pass through states of non-eruptive and non-magmatic unrest for various and prolonged periods of time. Volcanic hazards related to non-magmatic unrest can be highly violent and/or destructive (e.g., phreatic eruptions, secondary lahars), can lead into magmatic and eventually eruptive unrest, and can be more difficult to forecast than magmatic unrest, for various reasons. The duration of a state of non-magmatic unrest and the cause, type and locus of hazardous events can be highly variable. Moreover, non-magmatic hazards can be related to factors external to the volcano (e.g., climate, earthquake). So far, monitoring networks are often limited to the usual seismic-ground deformation-gas network, whereas recognizing indicators for non-magmatic unrest requires additional approaches. In this study we summarize non-magmatic unrest processes and potential indicators for related hazards. We propose an event-tree to classify non-magmatic unrest, which aims to cover all major hazardous outcomes. This structure could become useful for future probabilistic non-magmatic hazard assessments, and might reveal clues for future monitoring strategies.
\end{abstract}

Keywords: Non-magmatic unrest; Volcanic hazard; Forecasting; Volcanic surveillance; Event tree

\section{Introduction}

During long inter-eruptive periods of hundreds to thousands of years, a volcano passes through different stages of activity including periods of dormancy, quiescence, reawakening and unrest. Due to this very long-term behavior, hazard forecasting becomes challenging, in particular for short-term time frames (days to few months). So far, most volcanic hazard assessments have focused on magmatic unrest (e.g., Sparks 2003). Effective hazard assessment and risk mitigation during unrest depends on the early and reliable identification of changes in volcanic dynamics and their recognition as potential precursors to a hazardous event (Selva et al. 2012). Major uncertainties in the identification of the causative processes of unrest translate into uncertainties in short-term forecasting. The problem is made even more complicated by the intrinsic and almost inevitable subjectivity in the definition of unrest. Phillipson et al. (2013) defined volcanic unrest as the "deviation from

\footnotetext{
* Correspondence: dmitri.rouwet@ingv.it

${ }^{1}$ Istituto Nazionale di Geofisica e Vulcanologia, Sezione di Bologna, Bologna, Italy

Full list of author information is available at the end of the article
}

the background behavior of a volcano towards a behavior, which is cause for concern in the short-term because it might be a prelude to an eruption", a concept that we adopt in this study. Unrest depends also on the volcano itself, reflected by its background activity, and should thus be defined for each volcano separately (e.g., Potter 2014; Sandri et al. 2014).

If the cause of concern during a stage of volcanic unrest is the recognition of the migration from a magma reservoir (Figure 1), the volcano is in a stage of magmatic unrest. Hence, this process does not attest to processes and characteristics that are intrinsic of stagnant cooling magma batches at given P-T conditions such as convection or crystallization, which may contribute to degassing (Figure 1). If no evidence for "magma-on-the-move" exists, but concern remains high for any other reason, the volcano is in a phase of non-magmatic unrest. This apparently banal but highly practical distinction does not imply that recognizing non-magmatic unrest is easy. One important task of this study is to shed light on the detectable indicators of nonmagmatic unrest in its various ways. 


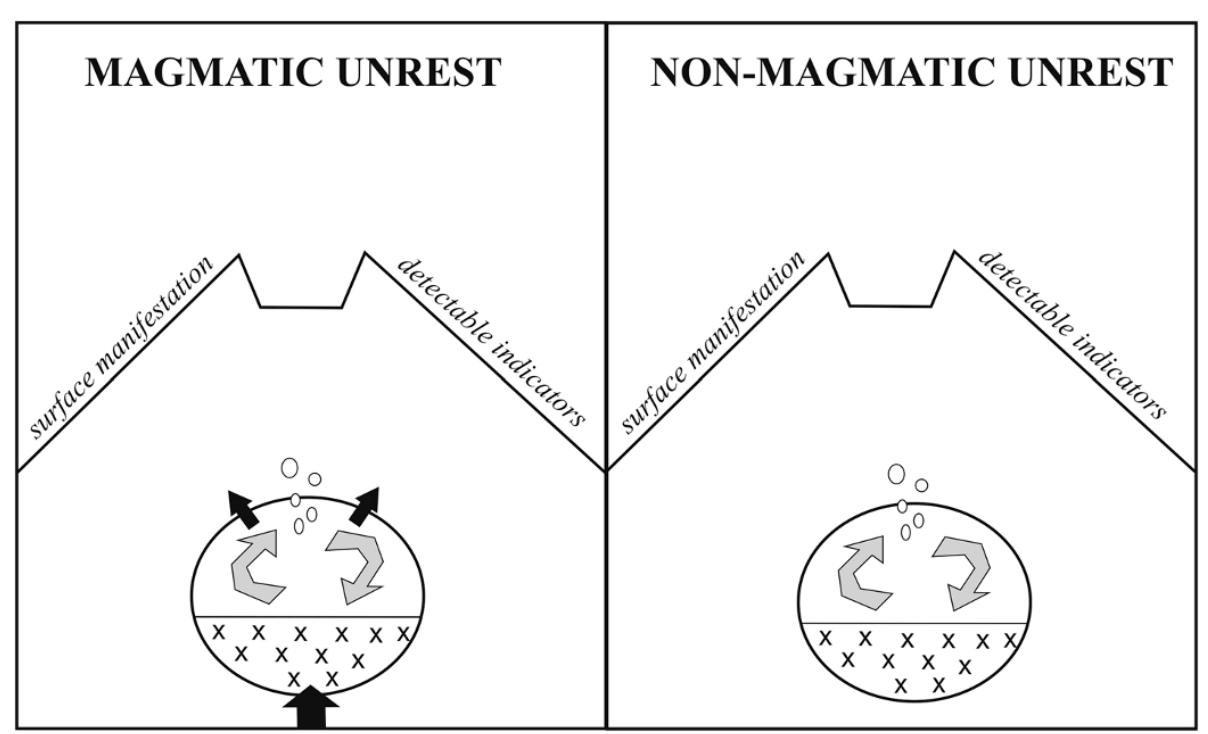

Figure 1 Magmatic vs non-magmatic unrest. A volcano is in a stage of magmatic unrest if volcanic unrest is caused by the migration from a magma reservoir (left), which we are able to recognize as such. If we cannot recognize magma migration (regardless whether it migrates or not), but concern remains high for any other reason, the volcano will be in a state of non-magmatic unrest (right). Magma convection and crystallization in a magma chamber are often not recognized as magma migrations, and thus would results in non-magmatic unrest.

Probabilistic methods can be applied to forecast volcanic activity across different timescales. Several tools have been developed and applied over the past decade including event trees (Newhall and Hoblitt 2002), some focusing only on magmatic eruptions (Bayesian Belief Network, BBN, Aspinall et al. 2003; Bayesian Event Tree for Eruption Forecasting, BET_EF, Marzocchi et al. 2004a, 2008; Sandri et al. 2009, 2012; Selva et al. 2012; Marzocchi and Bebbington 2012), others also focusing on long-term hazard assessments (Bayesian Event Tree for Volcanic Hazard, BET_VH, Marzocchi et al. 2010; Selva et al. 2010; Sandri et al. 2014; HASSET, Sobradelo et al. 2014). So far, the schemes for short-term hazard assessment have put only minor emphasis on evaluating phenomena associated to non-magmatic hazards, despite the fact that these have had significant economic and social impact in the past. Prominent examples of activity at volcanoes which did not probably involve magmatic eruptions include the phreatic activity at Soufrière de Guadeloupe in 1976 (Shepherd et al. 1979; Shepherd and Sigurdsson 1982), non-eruptive unrest at Campi Flegrei in the 1980's (Barberi et al. 1984; Dvorak and Mastrolorenzo 1991; Orsi et al. 1999; Chiodini et al. 2001, 2003), and the flank collapse of Casita volcano in 1998 (Kerle and van Wijck de Vries 2001), to name a few.

This paper reviews various non-magmatic unrest phenomena, in order to help recognize and track potentially hazardous outcomes. We will present an event tree to map the evolution of non-magmatic unrest along different stages, with an increasing level of detail. This event tree has not yet been applied to probabilistic hazard forecasting during stages of non-magmatic unrest, although it is intended to become the basis for a future BET_UNREST code. Adding this branch to the BET (Bayesian Even Tree) provides a means to assess all hazardous outcomes that should be considered in real-time updating of the BET model. The background idea is that "magma-on-the-move" is a necessity before a magmatic eruption. However, it is not a necessity for the evolution of different stages of non-magmatic unrest. Hence, we stress the importance of recognizing magma on the move to distinguish between magmatic and non-magmatic unrest. Here we present a concept for the recognition of precursory symptoms and resultant potential threats from nonmagmatic unrest activity.

\section{Non-magmatic hydrothermal unrest}

Many volcanoes hosting hydrothermal systems are in a state of quiescence (i.e. background activity) during prolonged inter-eruptive phases, manifested as lowtemperature fumarolic emissions (Giggenbach et al. 1990; Sturchio and Williams 1990; Giggenbach and Corrales Soto 1992; Sturchio et al. 1993; Fischer et al. 1997; Lewicki et al. 2000; Rouwet et al. 2009; Joseph et al. 2011, 2013; Chiodini et al. 2012), diffuse $\mathrm{CO}_{2}$ soil degassing and steaming ground (Cardellini et al. 2003; Werner et al. 2003, 2008; Bergfeld et al. 2006, 2012; Werner and Cardellini 2006; Lewicki et al. 2007a, 2007b; Mazot et al. 2011; Inguaggiato et al. 2012; Lewicki and Hilley 2014), thermal spring discharges (Taran et al. 2008; Taran and Peiffer 2009), low-activity crater lakes (Pasternack and Varekamp 1997; Taran et al. 
1998; Stimac et al. 2004; Rouwet et al. 2004, 2008, 2014; Taran and Rouwet 2008), and/or hydrothermal alteration (Getahun et al. 1996; Gehring et al. 1999; Salaün et al. 2011). Volcano-hydrothermal systems seem to develop more frequently in closed-conduit dome complexes and calderas (e.g. Yellowstone, Long Valley and Campi Flegrei), rather than cone-shaped central-conduit stratovolcanoes (Rouwet et al. 2015), and surface manifestations often reflect the local tectonic regime of the volcano (e.g., Mazot et al. 2011). Despite the relatively non-hazardous nature of such prolonged hydrothermal background activity, a profound knowledge of quiescent activity of individual volcanoes is necessary to understand the short- (daily) and long-term (seasonal, yearly) baseline behavior from which to deviate when evolving towards a state that causes concern.

\section{Hydrothermal eruptive unrest}

Eruptions during stages of non-magmatic unrest, by definition, do not deal with lava or juvenile tephra emission, as no magma migration is involved. However, besides lava and juvenile tephra, volcanoes are able to release fluids in an effusive or explosive manner. Below, we describe several observed mechanisms leading to such events.

\section{Effusive eruptive unrest}

Water effusion Volcano-hydrothermal systems can manifest non-explosive expulsion of water. A rise of the water level in volcano-hydrothermal systems can be caused by the interplay of (1) increased or prolonged infiltration of meteoric water into a hydrothermal system, (2) increased or prolonged condensation of steam into a nearsurface aquifer, (3) variations in the vapor pressure regime in a hydrothermal system, or (4) the rise of perched aquifers due to buoyancy effects of a rising bubble-rich or vapor-rich fluid front.

Variations in the phreatic level of an aquifer often pass visually unobserved, as the effect does not necessarily reach the surface. Nevertheless, changes in the water saturation state in a volcanic edifice can drastically change its mechanical and hydraulic conditions (Reid 2004). These variations in hydraulic regime in a volcano can be detected through self potential, microgravity, resistivity or VLF surveys (Finizola et al. 2003; Révil et al. 2004; Zlotnicki et al. 2006; Gottsmann et al. 2007; Fournier et al. 2009; Villasante-Marcos et al. 2014). Water level gauging in wells or flow rate measurements from (thermal) springs at volcano flanks is the most direct way, although few examples of frequent monitoring exist (Ingebritsen et al. 2001; Hurwitz et al. 2002; Taran and Peiffer 2009), which inevitably leads to the need for numerical modeling procedures to increase theoretical insights (Hurwitz et al. 2003; Todesco and Berrino 2005).
Variations of the water level in a hydrothermal system is most obvious when aquifers intersect the surface, through direct outpouring of water from wells or springs, or variations in the water level of crater lakes. El Chichón volcano (Mexico), in a state of non-magmatic unrest since soon after the 1982 Plinian eruptions, hosts a boiling spring which periodically discharges water towards its crater lake (Rouwet et al. 2004, 2008) (Figure 2). This particular dynamics results from the prolonged infiltration of meteoric water into the volcano-hydrothermal system which, together with the local boiling regime, creates a steam cap that leads to non-explosive water expulsion.

An intrinsically gravitationally unstable system is manifested as a near-boiling lake that occasionally drains and refills its water, without necessarily a clear cycle (in contrast to geysers) (Inferno Lake, New Zealand, Vandemeulebrouck et al. 2005; Boiling Lake, Dominica, Fournier et al. 2009; Di Napoli et al. 2013). Such lakes can be sustained above the regional aquifer by the drag force caused by a gas phase flowing through a liquid-filled permeable conduit. At equilibrium, the hydrostatic pressure of the water raised above the water table counterbalances the drag stress for each bubble. In order words, bubbles "carry" the lake. Moreover, denser cold water near the lake will be lifted by underlying hotter water, which needs to boil and bubble to keep the unstable cooler lake suspended.

Poás' crater lake Laguna Caliente peculiarly overflowed its stable and steep-walled crater lake basin from January to April 2005 (despite the dry season), a year before the onset of the 2006-ongoing phreatic eruption cycle. This sudden rise was probably induced by an upwelling vapor front beneath the crater lake, or the injection of a liquid (direct or as condensed steam) into the cooler lake.

Sulfur volcanism Sulfur is a low viscosity liquid between $\sim 116^{\circ}$ and $\sim 159^{\circ} \mathrm{C}$ (Oppenheimer 1992; Takano et al. 1994). If a fumarolic system is heated to $>116^{\circ} \mathrm{C}$ preexisting sulfur deposits in vugs and vents can be remobilized, manifested as a sulfur flow at the surface (Naranjo 1985; Oppenheimer 1992; Harris et al. 2004). This feature is a clear sign of heating of a previously colder system, and thus often the onset of a state of non-magmatic unrest. Recently, sulfur flows were observed at White Island (New Zealand, 2013); Poás (Costa Rica, in May 2005, 10 months before the onset of the 2006-ongoing phreatic eruption cycle) (Figure 3), Turrialba (Costa Rica, the morning of the 11 January 2012 phreatic eruption, G. González pers. comm.), andat Sulphur Springs, Soufrière (Dominica) in 1994, four years before an intense seismic swarm (J. Lindsay pers. comm.). "Sulfur volcanism" is exhibited as spectacular sulfur volcanoes, boiling sulfur ponds, or liquid sulfur pools at the bottom of active crater lakes, manifested at the surface as floating sulfur spherules (e.g., Lake Yugama, Kusatsu-Shirane volcano, Japan, Takano et al. 1994; Poás, 


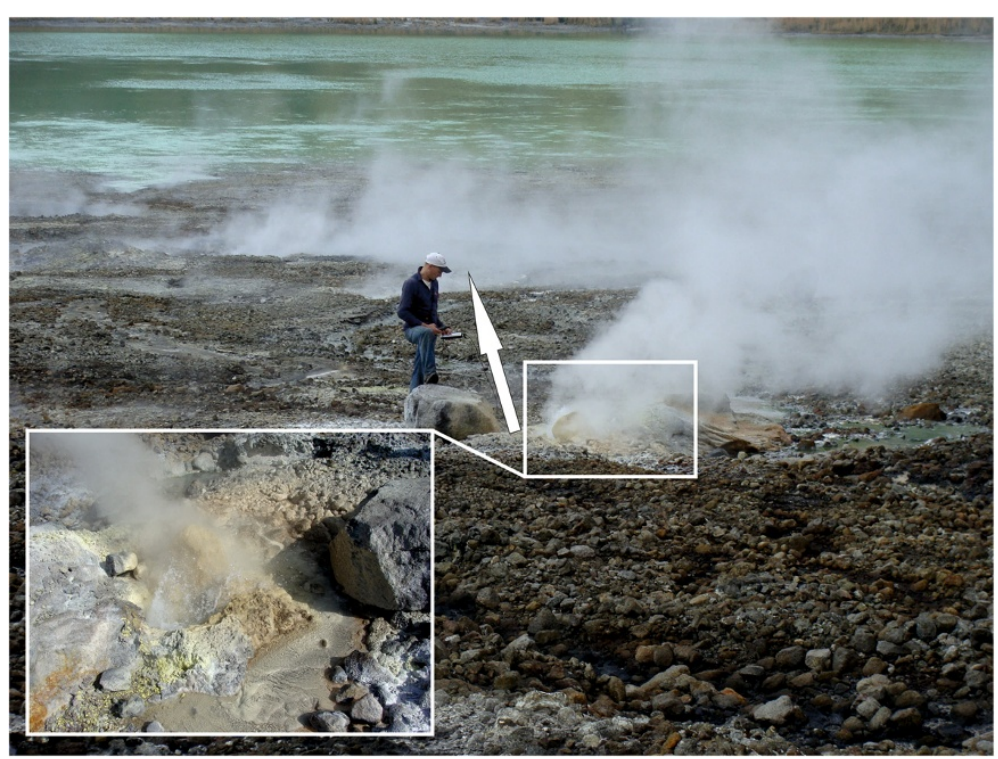

Figure 2 Water expulsion from a boiling spring discharging towards the crater lake (top) inside the active crater of El Chichón volcano, Mexico. The image in the inset shows a detail of the spring (Picture by Yuri Taran, November 2009).

Oppenheimer and Stevenson 1989, Oppenheimer 1992; Keli Mutu, Pasternack and Varekamp 1994).

\section{Explosive eruptive unrest}

Phreatomagmatic eruptions A phreatomagmatic eruption implies the presence of magma, and thus seemingly a state of magmatic unrest. Unfortunately, phreatomagmatic eruptions can occur without a clear precursor during a phase of non-magmatic unrest, (i.e. no signal of magma migration is recognized) as a major trigger mechanism for phreatomagmatic eruptions is decompression. If a stagnant magma body is present near the surface (common in the most active hydrothermal systems) it can easily be triggered into phreatomagmatic activity.

There are examples of decompression triggered phreatomagmatic eruptions, which occurred during non-magmatic hydrothermal unrest. During the period before the 25 September 2007 phreatomagmatic eruption of Ruapehu (New Zealand) the volcano was seismically quiet and the crater lake water temperature was low $\left(13^{\circ} \mathrm{C}\right.$, Christenson

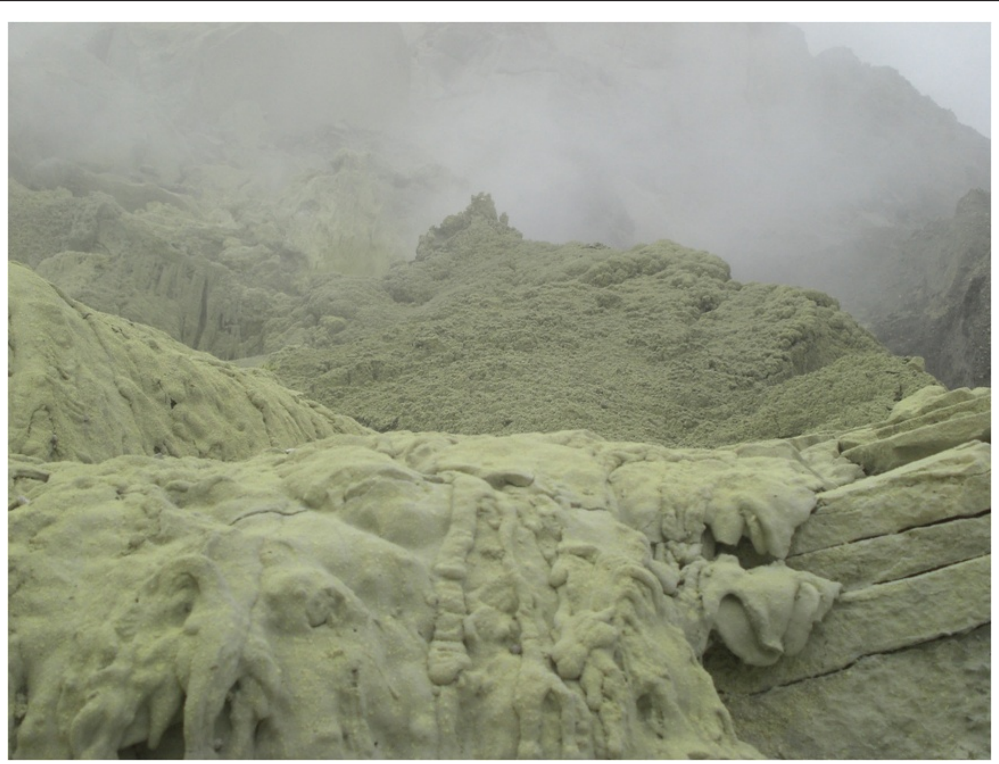

Figure 3 Deposit of the May 2005 sulfur flow at Poás volcano (Picture by D.R.). 
et al. 2010; Jolly et al. 2010), i.e. at that point, lacking any sign of magmatic unrest (Figure 4). The volcano experienced at that time a prolonged period of non-magmatic hydrothermal unrest. Volcano-tectonic earthquakes and volcanic tremor occurred only 10 minutes and 1 minute, respectively, before the eruption (Jolly et al. 2010). Within the practicality of volcano monitoring, precursory signals for such phreatomagmatic eruptions remain extremely difficult to recognize in time. The eruption itself was of short duration ( 1 minute), but violent, and injured two climbers. The phreatomagmatic eruption partially expelled the crater lake, triggering two lahars down Ruapehu's flanks (see section Lahars, volcanic debris flows, floods and jökulhlaups) (Figure 4) (Kilgour et al. 2010).

Phreatic eruptions Several definitions are available for phreatic eruptions (e.g., Barberi et al. 1992; Mastin 1991; Browne and Lawless 2001; Rouwet and Morrissey 2015, and references therein) which are not necessarily mutually consistent. Phreatic eruptions are triggered by the input of fluids and heat of magmatic origin into a shallow aquifer (sometimes into a lake), followed by overpressurization of the hydrothermal system, but without the eruption of juvenile magmatic material (Figure 5). In many cases, phreatic eruptions are ubiquitous precursors to magmatic eruptions of both explosive or effusive nature, or could serve as the decompression mechanism prior to phreatomagmatic eruptions. Phreatic eruptions often occur during prolonged periods of non-magmatic hydrothermal unrest (e.g., Pisciarelli, Campi Flegrei), and can occur as a single, major event, or as minor events within a phreatic eruption cycle (Rouwet et al. 2014). Given the state of hydrothermal unrest and the high compressibility of fluid phases (gas, vapor and water), precursory signals are buffered by the hydrothermal system within the time-frame hydrothermal systems are often monitored (yearly, monthly or weekly in the best case). The input of mass and heat through a magmatic fluid pulse into a shallow aquifer, the instigator of a phreatic eruption, is often a short-term and too lowamplitude event which passes unobserved within the timeframe of monitoring set-ups, or discontinuous geophysical surveys will not be able to detect a minute to hour-scale sudden heat and fluid input. Continuous temperature monitoring of hydrothermal systems (e.g., real-time FLIRimaging, T-gauging) could perhaps reveal a short-term precursor for phreatic eruptions (Ramírez et al. 2013).

Secondary mineral precipitation after prolonged alteration, or the presence of low-permeable elemental sulfur can seal hydrothermal systems by reducing permeability of country rock increasing the possibility of localized pressurization, one of the possible constraints to reach a pressure threshold prior to phreatic eruptive activity. Monitoring the evolution of alteration mineralogy, microgravity, hydrology and fluid geochemistry could lead to an indication of the most probable locus and timing of a future phreatic eruption.

Hydrothermal explosions Some volcano craters contain subaerial or sublacustrine geyser-like boiling springs. Geyser eruptions are boiling-point eruptions, which only expel water (Mastin 1995). These non-violent eruptions

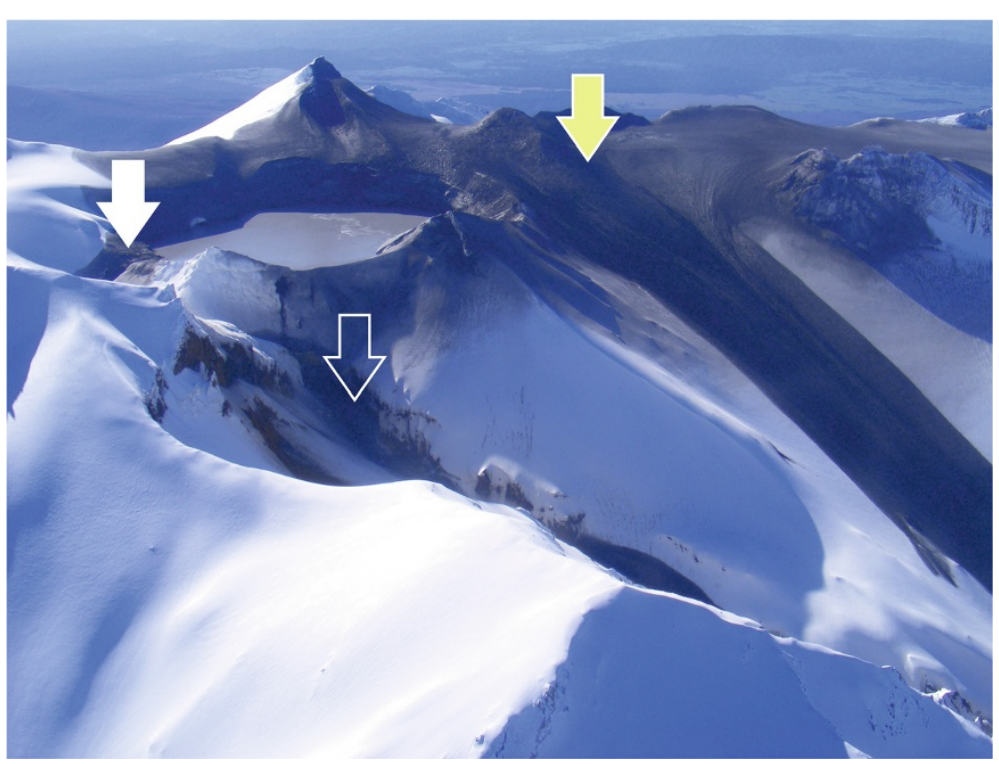

Figure 4 View of the Ruapehu summit area after the September 2007 "surprise" phreatomagmatic eruption. The yellow arrow indicates the tephra fall; the open white arrow indicates the proximal deposit of the lahar, that was generated after partial crater lake expulsion due to the phreatomagmatic eruption (filled white arrow) (Picture by Karoly Németh). 


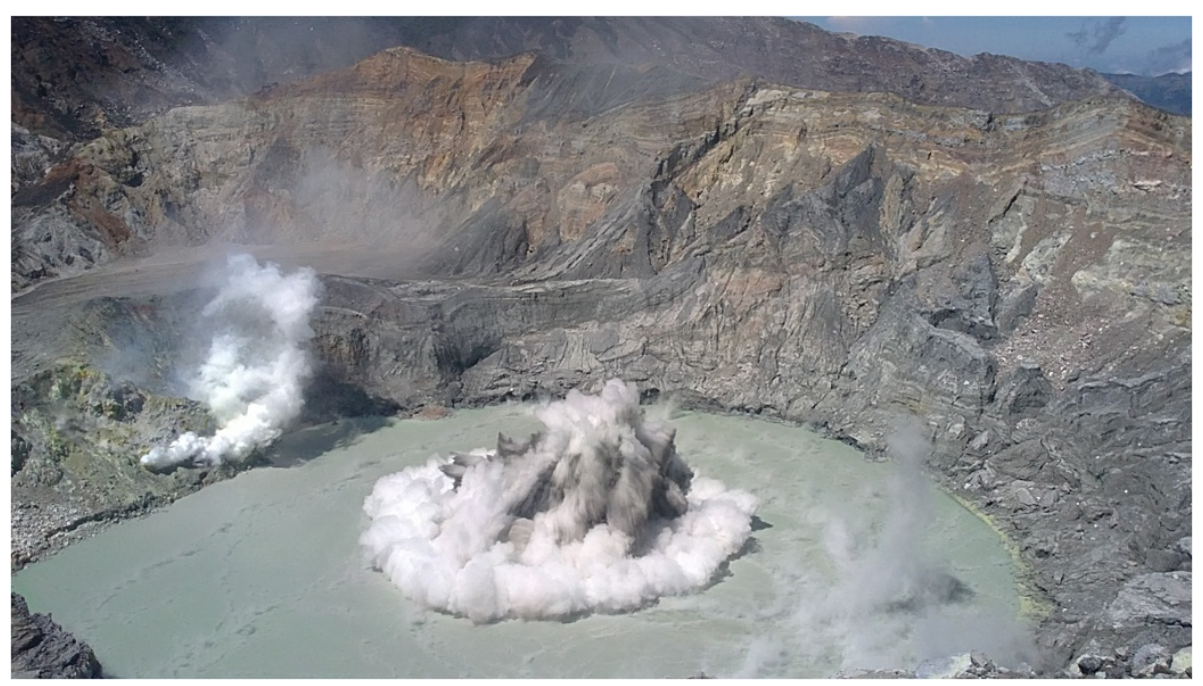

Figure 5 Phreatic eruption at Poás volcano breaching the Laguna Caliente crater lake (Picture by A.B. Castro). Phreatic eruptions may result in pyroclastic density currents and non-juvenile tephra fall out.

occur when a buried fluid near boiling conditions is depressurized leading to the creation of a bi-phase liquid-vapor mixture, expansion and, finally, explosion (White 1967; Kieffer 1984). If we assume a constant water recharge and heating during intereruptive periods, what causes the cyclicity of geyser eruptions? A key property of the geyser plumbing system is its heterogeneous geometry and/or permeability (Kieffer 1984; Ingebritsen and Rojstaczer 1993, 1996). During reservoir refill, this leads to a discontinuous rise in water level, and thus a step-wise variation in hydrostatic pressure: boiling will eventually occur when higher permeable zones (e.g., fractures) are filled slowly, while boiling will be suppressed when less permeable parts (e.g., narrow conduits) are quickly filled (Kieffer 1984; Ingebritsen and Rojstaczer 1993). Brown et al. (1989) and Dowden et al. (1991) concluded that frequent (every $10 \mathrm{~min}$ ) and short $(10 \mathrm{sec})$ geyser-like eruptions offered an efficient means to dissipate energy at the 1985-1988 Laguna Caliente crater lake (Poás volcano, Costa Rica). Overlying liquid water will be disrupted when a submerged vent or fumarole filled with vapor under pressure is subjected to a pressure release paired with the water ejected upward (Dowden et al. 1991). It is noteworthy that Laguna Caliente passed a phase of lake level drop, due to enhanced lake evaporation that steadily decreased the hydrostatic pressure, teasing the underlying system with near-boiling conditions, and thus potential geysering. During complete dry-out of the lake in 1989, Poás exhibited nearly continuous geysering (Dowden et al. 1991). Since 2006, Laguna Caliente exhibits a similar behavior (Rymer et al. 2009): a phreatic eruption cycle and contemporaneous lake level decrease. It sounds reasonable that the ongoing periodical fluid injections in more peaceful manner into Laguna Caliente are controlled in some way by a geyser-like mechanism. Consequently, more powerful eruptions at a crater lake are rather phreatic, which can eventually destroy geyser plumbing systems.

Limnic Nyos-type gas release Deep lakes in maars, craters and calderas can become hazardous if they are fed by gas-rich (mainly $\mathrm{CO}_{2}$ ) regional meteoric groundwater (Tassi and Rouwet 2014). Due to the hydrostatic pressure of the lake water column, the entering gas remains dissolved in the lake bottom waters (hypolimnion). The lethal gas $\left(\mathrm{CO}_{2}\right.$ is an asfixiating gas, denser than air) can be released from the lake when (1) the lake will periodically overturn during the cold season, when colder and thus denser surface waters sink towards the lake bottom, (2) the dissolved gas pressure at depth exceeds the hydrostatic pressure (spontaneous release by supersaturation), or (3) an external trigger disturbs the chemical and thermal lake stratification (e.g., an earthquake, rock fall into the lake, strong winds, internal waves, the sudden input of cold rain water during rainstorms, etc.) (see Kusakabe 2015, for a review). Explosive gas release occurred in 1984 and 1986 at Lake Monoun and Lake Nyos (Cameroon), respectively. The Lake Nyos event killed $>1,800$ people by $\mathrm{CO}_{2}$-asfixiation (Kling et al. 1987).

At the lake surface, "Nyos-type" lakes appear peaceful, and the only way to recognize a potential $\mathrm{CO}_{2}$-accumulation in bottom waters is by lowering a CTD-probe (conductivity-temperature-depth), dissolved gas-pressure probes, or by sampling the lake water at depth, followed by chemical analyses (Tassi and Rouwet 2014). Once a $\mathrm{CO}_{2}$-accumulation is recognized and the $\mathrm{CO}_{2}$ influx rate is known, it can be estimated when such lakes reach near-critical pressures of dissolved gases at depth 
(Kusakabe 2015). The only way to mitigate a limnic gas burst is by artificially degassing the lake bottom waters, lowering pipes into the deep water layers, inducing degassing through the gas self-lift principle. Such pipes are efficiently degassing Lake Nyos since 2001, leading to safe gas contents in the near future (Kusakabe 2015). Many of the deep volcanic lakes world-wide remain unstudied, and it is thus unknown if these lakes are potentially hazardous or not.

\section{Hydrothermal non-eruptive unrest \\ Gas emission}

An increase in volcanic degassing can occur by (1) gas exsolution upon decompression, when a deeper magma rises towards the surface (Aiuppa et al. 2002, 2004), (2) dynamic magma convection inside the magmatic plumbing system, driven by the density difference between lowerdensity non-degassed and higher-density degassed magma (Kazahaya et al. 1994), or (3) crystallization of a stagnant, cooling magma batch and gas exsolution as the gas fraction in the magma reservoir increases with respect to the melt towards gas supersaturation (Oppenheimer 2011). The first process will generally be accompanied by seismic activity, deformation, variations in gas composition or even magmatic eruptions, and indicate a state of magmatic unrest, and is thus outside the scope of our review. The second process can be responsible for long-term degassing of large-volume magma bodies. Depending on the plumbing systems and magma depth, magma convection can be accompanied by signs of magmatic unrest (and eventually eruptions, e.g., Stromboli), or not (e.g., prolonged high-T fumarolic degassing). The third process is more complex in terms of time, space and its effect on surface manifestations. Magma crystallization can occur without any physical-chemical indicators measured at the surface, and the crystallization history will only be revealed when the magma is finally erupted. This type of degassing and related heat transfer, a necessary constraint to sustain a hydrothermal system, can explain prolonged periods of non-magmatic unrest, as there is no evidence of migration from a magma reservoir. Depending on the crystallization rate, depth and size of the magma batch, the period of "gas unrest" can cover entire inter-eruptive periods of volcanoes. Such unrest is often detected at passively degassing, closed-conduit volcanoes, often with long-lived active hydrothermal systems.

A few volcanoes are characterized by long-term, hightemperature $\left(700-900^{\circ} \mathrm{C}\right)$ fumarolic degassing without further evidence of magma migration (e.g., Momotombo, Nicaragua, Menyailov et al. 1986; Satsuma-Iwojima, Japan, Shinohara et al. 1993, 2002; Kudryavy, Kuril Islands, Taran et al. 1995). Despite the fact that magmatic temperatures of the gases suggest the presence of a shallow magma body (hundreds of meters or less), no recent eruptions have occurred. The last major eruption at Satsuma-Iwojima occurred $~ 500$ years ago, and high-T fumarolic degassing is reported for the past $\sim 800$ years (Shinohara et al. 2002). At Momotombo, the last magmatic eruption occurred in 1905 (lava flow, Menyailov et al. 1986). Slow crystallization and/ or dynamic magma convection of a large stagnant magma body can explain long-term degassing. A major question remains: why do some high-temperature degassing volcanoes pass through decade-long phases of non-magmatic unrest, while other high-temperature degassing volcanoes frequently evolve into magmatic unrest, or eventually culminate into eruptive activity? The answer is probably found in the magma volume and magma recharge rate: large magma bodies with slow or absent magma refill will tend to degas without evolving towards eruptions.

The release of acidic gas species $\left(\mathrm{SO}_{2}, \mathrm{HCl}, \mathrm{HF}\right)$ during prolonged degassing in a phase of non-magmatic unrest can reduce the quality of human activities near volcanoes (e.g., agriculture, tourism) (van Manen 2014). The presence of $\mathrm{SO}_{2}$ and $\mathrm{HCl}$, clearly magmatic gases, does not necessarily imply the migration of a magma, as exsolution of both species can occur through the above processes (2) and (3). For open-conduit volcanoes, massive plume degassing can become very harmful (e.g., Masaya volcano, Nicaragua, Williams-Jones et al. 2003; Martin et al. 2010; Merapi, Java-Indonesia, Zimmer and Erzinger 2003), although in these cases magmatic unrest is ubiquitous. Besides the direct hazardous impact of acidic gas plumes, the absorption of acidic gases in humid air can cause acid rain and the formation of "dead zones" downwind volcano flanks (e.g., at Poás and Turrialba volcanoes, Costa Rica) (Rymer et al. 2009; van Manen 2014).

\section{Acid contamination}

The prolonged infiltration of acidic fluids into a volcanic edifice dissolves the host rock and can lead to (1) mechanical instability of volcano flanks, and thus a higher probability of flank failure (section Ground deformation), or (2) the dispersion of contaminants (e.g., heavy metals, fluorine, As, $\mathrm{Hg}$, extreme acid waters) into the hydrologic network and regional aquifers around a volcano (Sriwana et al. 1998; Delmelle and Bernard 2000; Varekamp et al. 2001; van Rotterdam-Los et al. 2008; van Hinsberg et al. 2010). When such fluids are used for direct (drink water) or indirect (irrigation) human consumption, entering the food cycle, this long-term volcano-related process poses a health risk for the surrounding people (e.g., fluorisis, Löhr et al. 2005).

The most striking example of this situation is seepage from the hydrothermal system beneath the crater lake of Kawah Ijen volcano (Java, Indonesia), feeding the Banyupahit stream ("bitter river", Delmelle and Bernard 2000; van Hinsberg et al. 2010). Since the last magmatic 
eruption in 1817, Kawah Ijen has mainly been in a state of non-magmatic unrest, with the occurrence of only phreatic or geyser-like eruptions (Newhall and Dzurisin 1988). Nevertheless, the volcano hosts the largest reservoir of acidic surface water on earth, continuously fed by the input of magmatic gases and volatilized metals (Delmelle and Bernard 1994; Delmelle et al. 2000). Other examples, although with less hazardous impacts, are Río Agrio ("bitter river") at Copahue volcano (Argentina; Varekamp et al. 2001), Río Agrio at Poás volcano (Costa Rica; Rowe et al. 1995), and Ciwidey river at Patuha volcano (Java, Indonesia; Sriwana et al. 1998).

\section{Ground deformation}

Flank failure and sector collapse Acid fluids in volcanichydrothermal systems dissolve volcanic host rocks. Prolonged chemical leaching can finally result in physical rock removal, when such fluids exit at the volcano flank through acid saline thermal springs. Within the lifetime of hydrothermal systems, this rock mass removal can modify the morphology and weaken the mechanical stability of the volcanic edifice, increasing the probability of avalanches and sector collapses, even during periods of magmatic quiescence (Voight et al. 1983; López and Williams 1993; Kerle and van Wijck de Vries 2001; Reid 2004; Jolly et al. 2014; Fournier and Jolly 2014). Intense fumarolic activity at volcanic domes, not recently fed by a rising magma, can weaken the mechanical stability of the dome, eventually leading to collapse. Resulting pressure drop after unloading of the volcano flank or dome can lead to increased degassing or can trigger phreatic eruptions. The best physical evidence of acidic fluid dispersion and rock leaching within a volcanic edifice is given by seeping crater lakes (Rowe et al. 1995; Kempter and Rowe 2000; Varekamp et al. 2001; Taran et al. 2008; Delmelle et al. 2015).

Acid dispersion is an indication of eventual collapseprone sectors of a volcanic edifice, but the presence of a less extreme hydrothermal system can already be sufficient to cause massive edifice collapse (López and Williams 1993; Reid 2004). Fluid-pressure evolution within a heterogeneous volcanic edifice is extremely complex, and depends on hydraulic (permeability and porosity) and thermal properties of the rock (Reid 2004; Fournier and Chardot 2012). To anticipate hazardous collapses intensive monitoring of pore-fluid pressure in the hydrothermal system and/or detailed deformation surveys (e.g., INSAR) of the edifice are key.

Ground deformation due to hydrothermal activity Long-term ground deformation often occurs at calderas without the occurrence of an eruption, or clear signals of magma migration (Rabaul, Papua New Guinea; Long Valley Caldera, Evans et al. 2002; Lewicki et al. 2007b; and "supervolcano" Yellowstone, USA, Dzurisin and Yamashita 1987; Werner and Brantley 2003; Lowenstern and Hurwitz 2008; Bergfeld et al. 2012; Chiodini et al. 2012; Lowenstern et al. 2014; Campi Flegrei, Italy, Amoruso et al. 2014). The discussion as to whether the unrest at Campi Flegrei since the 1980's is magmatic (Bianchi et al. 1987; Bonafede et al. 1986; Gottsmann et al. 2006), or non-magmatic (Casertano et al. 1976; Bonafede 1991; De Natale et al. 1991; Gaeta et al. 1998) is still ongoing. Recently, the tendency to explain the uplift by the expansion of the underlying hydrothermal system has become more plausible as it is supported by decade-long monitoring time series (geochemistry, geodesy, geophysical surveys) (Chiodini et al. 2001, 2003; Todesco et al. 2003), even though the deformation pattern may be explained by alternative models (e.g., Amoruso et al. 2014). The Campi Flegrei unrest, causing major concern also because the caldera is highly populated, is an example of prolonged hydrothermal noneruptive unrest manifested as ground deformation paired with diffuse degassing.

The most convincing argument to explain the uplift phases at Campi Flegrei by hydrothermal circulation is an observed time-lapse of $\sim 100$ days of increased diffuse degassing following the uplift pulses (Chiodini et al. 2003). This implies that both processes have a common cause, which probably finds its origin in the input of a deep fluid, which may or may not be released by the underlying magma. The time-lapse between the "fast" deformation and "slow" degassing is due to the difference between the immediate elastic expansion of the highly altered rocks (De Natale et al. 1991), and the slower fluid rise (Chiodini et al. 2003). An additional argument in favour of the hydrothermal system being the cause of the observed bradyseismicity (ground deformation) is the thermal energy release by steam injection into the shallow system, an order of magnitude higher than the energy release by seismicity. Within the present view, as long as the Campi Flegrei caldera only deforms and degasses, without the occurrence of volcanorelated seismicity (D'Auria et al. 2011), the current unrest is better defined as non-magmatic hydrothermal unrest. At Long Valley, following large seismic events and widespread passive $\mathrm{CO}_{2}$ degassing there was debate as to whether the inflation was magmatic or hydrothermal in origin (Battaglia et al. 2003; Battaglia and Vasco 2006). A full range of methods and monitoring techniques (geophysics, seismology, geochemistry) is needed to better distinguish whether the cause of deformation is magmatic or non-magmatic.

\section{Non-magmatic tectonic unrest}

A volcano enters in a state of non-magmatic tectonic unrest when a seismic event (e.g. tectonic earthquake or seismic swarm) in the absence of any recognition of magma migration, causes concern. Despite the probable absence of 
indicators, other than the tectonic event itself, volcanoes in a delicate equilibrium (e.g., active hydrothermal systems) could enter a state of tectonic unrest because of the seismic event. Considering an already close-to-critical pressure state, the physical equilibrium beneath mineral caps or above chilling margins of magma bodies can be easily disturbed by major tectonic earthquakes, which can induce volcanic unrest (magmatic or not) or eventually trigger phreatic or phreatomagmatic eruptions (Brodsky et al. 1998; Ichihara and Brodsky 2006; Manga and Brodsky 2006).

Within the scope of the present study, the introduction of seismic events as a possible "eruption or unrest trigger" should be supported by (1) the probability of coincidence between an earthquake and an eruption, or an earthquake and an evolution from volcanic quiescence to unrest, and (2) the state of unrest of the volcano before the earthquake. Correlations between large tectonic earthquakes and major volcanic eruptions up to distances of 500-1000 km are found, with time lapses between the earthquake and eruption even up to 30-35 years (Marzocchi 2002; Marzocchi et al. 2002, 2004b). It is not excluded that lower magnitude earthquakes (especially if the epicentre is near the volcano), or major earthquakes at larger distances could possibly affect the state of unrest of a volcano (e.g., Walter and Amelung 2007). Detecting a change in the state of unrest caused by an earthquake of any kind is a lot more subtle than it is for extensively reported volcanic eruptions (e.g., increased heat flux, Delle Donne et al. 2010). A major problem in calculating the probability that the state of unrest is changed by the earthquake is not only to know how many times a volcano changed its state of unrest due to the earthquake, but also to know how many times the many other volcanoes did not change their state of unrest, despite the earthquake. For this reason, the pre-tectonic unrest state of the volcano should be known for as many volcanoes as possible, as seismic events are possible at any moment and place in a subduction tectonic setting.

Coinciding seismic and eruptive activity has been reported for hydrothermal systems and volcanoes in unrest (Healy et al. 1965; Hurst and McGinty 1999; Christenson 2000; Christenson et al. 2007, 2010; Ohba et al. 2008; Watt et al. 2009). The time lapse between the tectonic earthquake and the eventual variation in the behaviour of the volcano causing concern, can be short (hours to days) or long (weeks to months, to even several years, Marzocchi 2002; Eggert and Walter 2009). A short time lapse between tectonic earthquakes and volcanic events is observed for the November 1964 and 2006 Raoul crater lake breaching eruptions (7 days after, Healy et al. 1965; Christenson et al. 2007), for post-earthquake deformation and increased seismicity at Long Valley Caldera (within 5 days after, Linde et al. 1994), for increased heat flow from volcanoes worldwide after major tectonic earthquakes (>Mw 7.9) (3-5 days after, Delle Donne et al. 2010), and for a phreatic eruption at Laguna Caliente crater lake, Poás volcano (Costa Rica), four days after a Mw 6.2 earthquake at $6 \mathrm{~km}$ from the volcano in January 2009.

Not surprisingly, the dynamic stress created by the seismic surface wave is a major cause in disrupting the delicate equilibrium in magmatic-hydrothermal systems (Hill 2008; Delle Donne et al. 2010) switching from hydrothermal to tectonic unrest.

\section{Event tree for non-magmatic unrest}

Figure 6 proposes the structure of the non-magmatic unrest branch of the event tree that, for now, serves as a classification system for non-magmatic unrest. The branch first discriminates between a hydrothermal and tectonic state of unrest.

Many volcanoes experience a hydrothermal unrest phase that lasts for years, decades or even centuries, which can eventually evolve into eruptive or non-eruptive activity and related hazardous outcomes. This long-term constant behavior often makes it difficult to recognize how hydrothermal unrest can lead to related hazards in the shortterm. Hydrothermal unrest can lead to non-magmatic eruptions, which can be explosive or effusive. Where the driving agent in magmatic eruptive unrest is magma, water (liquid or vapor, and occasionally liquid sulfur or gas) is the driving fluid and main eruptive product during nonmagmatic eruptive unrest. This water is part of the volcanic edifice or its subsurface parts (i.e., hydrothermal aquifers, springs, rivers or crater lakes), and its expulsion can be effusive or explosive (phreatic, "surprise" phreatomagmatic, geyser-like water explosions and Nyos-type limnic gas burst). On the other hand, non-eruptive hydrothermal unrest can also lead to volcanic hazards after prolonged gas emission, acidic fluid infiltration into aquifers, soils and the hydrologic network, or deformation induced by a rising fluid front (i.e., bradyseismicity).

A state of non-magmatic unrest can be also characterized by the occurrence of earthquakes, unrelated to magma migration. Non-magmatic tectonic unrest can escalate into non-magma related seismic activity, or earthquake triggered tsunamis at subaqueous volcano flanks.

In the next sections, we follow that structure of the proposed event tree (Figure 6) to enumerate all potential hazards that such phenomena may cause in volcanic areas. In doing so we try to organize the potential hazards related to non-magmatic phenomena in order to provide the basis for a probabilistic quantification of the related hazards.

\section{Major hazards related to non-magmatic unrest}

Within the classification purpose of this review, the hazardous event can (1) only result from the previous causative 


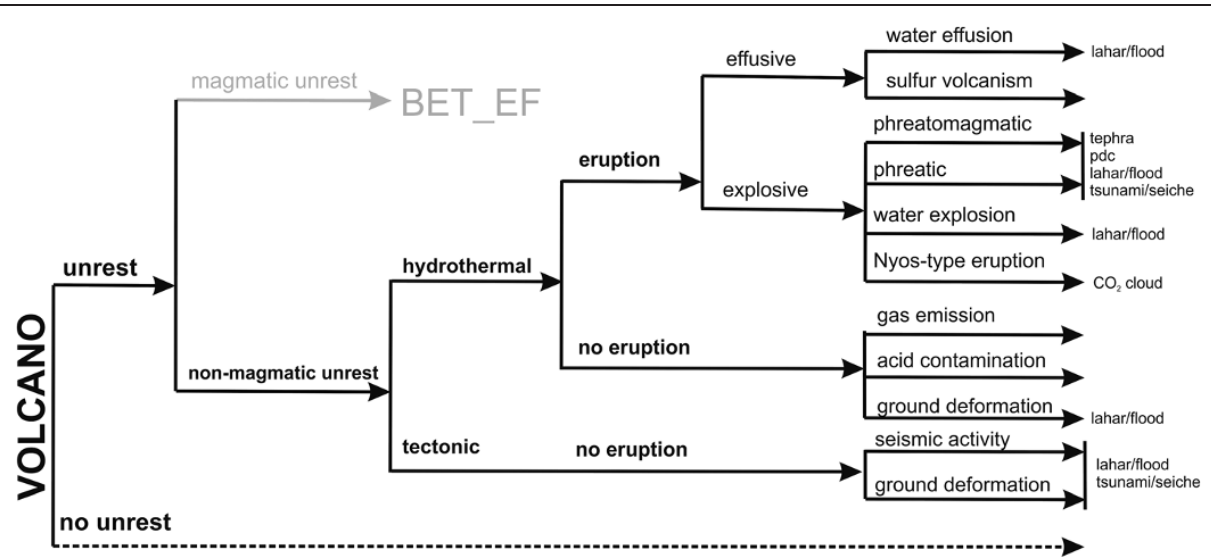

Figure 6 Proposed event tree for non-magmatic unrest. An event tree for magmatic unrest (BET_EF; in grey) is dealt with in previous studies (Marzocchi et al. 2004a, 2008; Sandri et al. 2009, 2012).

conditions (followed track) imposed by the event tree structure, and (2) not occur contemporaneously with another hazardous event, resulting from a different track. As the aim is to include all possible tracks that possibly lead to a hazard, all branches of the event tree have to exist and be possible at all time. A key point is that we do not know which track will be followed by the volcano and each new signal of the volcano challenges the user of the event tree to update and possibly even change track towards a different hazard, when describing non-magmatic unrest.

From the event tree structure it is clear that mass removal events (e.g. lahars, flood, tsunamis, ground deformation, jökulhlaups and flank collapses) can have several causes, depending on the state of unrest the volcano passes through. This principle gets even more complicated if external water (e.g., torrential rain ) disturbs the state of unrest of a volcano. Besides having implications for future probabilistic hazard assessment, the potential for external water to influence the system highlights the need to a larger variety of monitoring methods, both internal (e.g., to better track hydrothermal activity) and external to the volcano (e.g., to track the weather). We now scan the event tree from right to left (Figure 6), to recognize indicators of non-magmatic unrest as we should aspire to track in monitoring networks.

\section{Pyroclastic density currents and tephra fall out}

Phreatomagmatic and phreatic eruptions may result in pyroclastic density currents (PDC) and tephra fall out. The 1963 Surtsey eruption off the coast of Iceland is the first well-documented phreatomagmatic eruption (Thorarinsson 1967) to show eruption dynamics. Phreatomagmatic and phreatic eruptions are short-lived explosions accompanied by an upward rush of black tephra (Kokelaar and Durant 1983) jets spread into cockscomb or cypress tree shapes (Kokelaar 1983) (Figure 5). Water-dominated hydrothermal systems (e.g., crater lakes, submarine settings) favor the generation of Surtseyan eruptions (Rouwet and Morrissey 2014a,b). During the phreatomagmatic eruptions at Lake Voui on Ambae Island in 2005, a tuff cone was constructed from material deposited from subaerial tephra jets leading into subaqueous PDCs after column collapse (Németh et al. 2006). Base surges are also common features that accompany tephra jets (Belousov and Belousova 2001; Németh et al. 2006). Phreatic eruptions appear extremely similar in morphology and dynamics (explosivity, Figure 5) but lack the injection of magma. The main distinction is the absence of juvenile material in the erupted products.

\section{Lahars, volcanic debris flows, floods and jökulhlaups}

A lahar consists of high-concentration sediment-charged flows that occur at volcanoes (Scott 1988; Manville et al. 2009; Pistolesi et al. 2014). Lahars are generated when three requisites are met: (1) a trigger mechanism that provides a sudden availability of sufficient water, (2) the presence of abundant loose volcanic debris along the flow path, and (3) steep slopes to increase gravitational flow (Vallance 2000; Pistolesi et al. 2014). Lahars can be primary or secondary. The former are instigated by eruptive activity (e.g., Nevado del Ruíz 1985, Pierson et al. 1990), and thus within a stage of magmatic unrest. The latter result from post-eruptive mobilization of unconsolidated volcanic debris (e.g., de Bélizal et al. 2013), sometimes even originating from a neighboring erupting volcano. The indefinite time between the eruption and the secondary lahar implies that the volcano can have re-entered into a state of non-magmatic unrest or even non-unrest, or that the occurrence of the lahar itself is independent of the actual state of unrest of the volcano.

Any process that suddenly liberates large amounts of water other than a magmatic eruption can trigger a lahar within a state of non-magmatic unrest. Rainfall-triggered lahars are arguably the most hazardous secondary events at volcanoes (e.g., Volcán de Fuego de Colima, Mexico, 
Capra et al. 2010, post-1991 Pinatubo eruption, Philippines, Pierson et al. 1992; Rodolfo et al. 1996; post-1965 Irazú eruptions, Costa Rica, Pavanelli 2006). Another frequent hazardous scenario to generate lahars are sudden expulsions of crater lake water after phreatic eruptions or crater failure (Mastin and Witter 2000; e.g., 1919, 1966, 1990 Kelud eruptions, Indonesia, Neumann van Padang 1960, Zen and Hadikusumo 1965; Thouret et al. 1998; 1965 Taal eruption, Philippines, Moore et al. 1966; Ruapehu 2007, Kilgour et al. 2010).

Increased heat transfer from a hydrothermal system into a glaciated volcanic edifice can lead to sudden ice melt. In general, any snow-capped volcano is laharprone even during stages of non-magmatic unrest, when sudden snow melt is induced (e.g., Cotopaxi, Ecuador, Hall et al. 2004; Mothes et al. 2004, Pistolesi et al. 2013, 2014). For snow-covered summits of crater lake bearing volcanoes entrainment of ice-slurry along the lahar flow path can also provide an additional water source (e.g., 1953, 1995 and 2007 Ruapehu eruptions, New Zealand; Nairn et al. 1979; Blong 1984; Cronin et al. 1997; Kilgour et al. 2010). A less hazardous scenario may include a newborn crater lake which fills a pre-existing previously snow-covered summit crater, with potential to eventually breach or overflow if melt water input continues (e.g., Chiginagak-2005, Alaska, Schaefer et al. 2008) (Figure 7). A more hazardous case is a subglacial lake with sudden and catastrophic melt water release which results in a jökulhlaup. Jökulhlaup is an Icelandic term and refers to a subglacial outburst flood (Björnsson 2002). The remaining ice mass can be entrained to add bulk mass to the flood, besides the entrainment of rock mass. Jökulhlaups can result from seasonal ice melting, heat input (non-magmatic unrest) or subglacial volcanic eruptions (magmatic unrest).

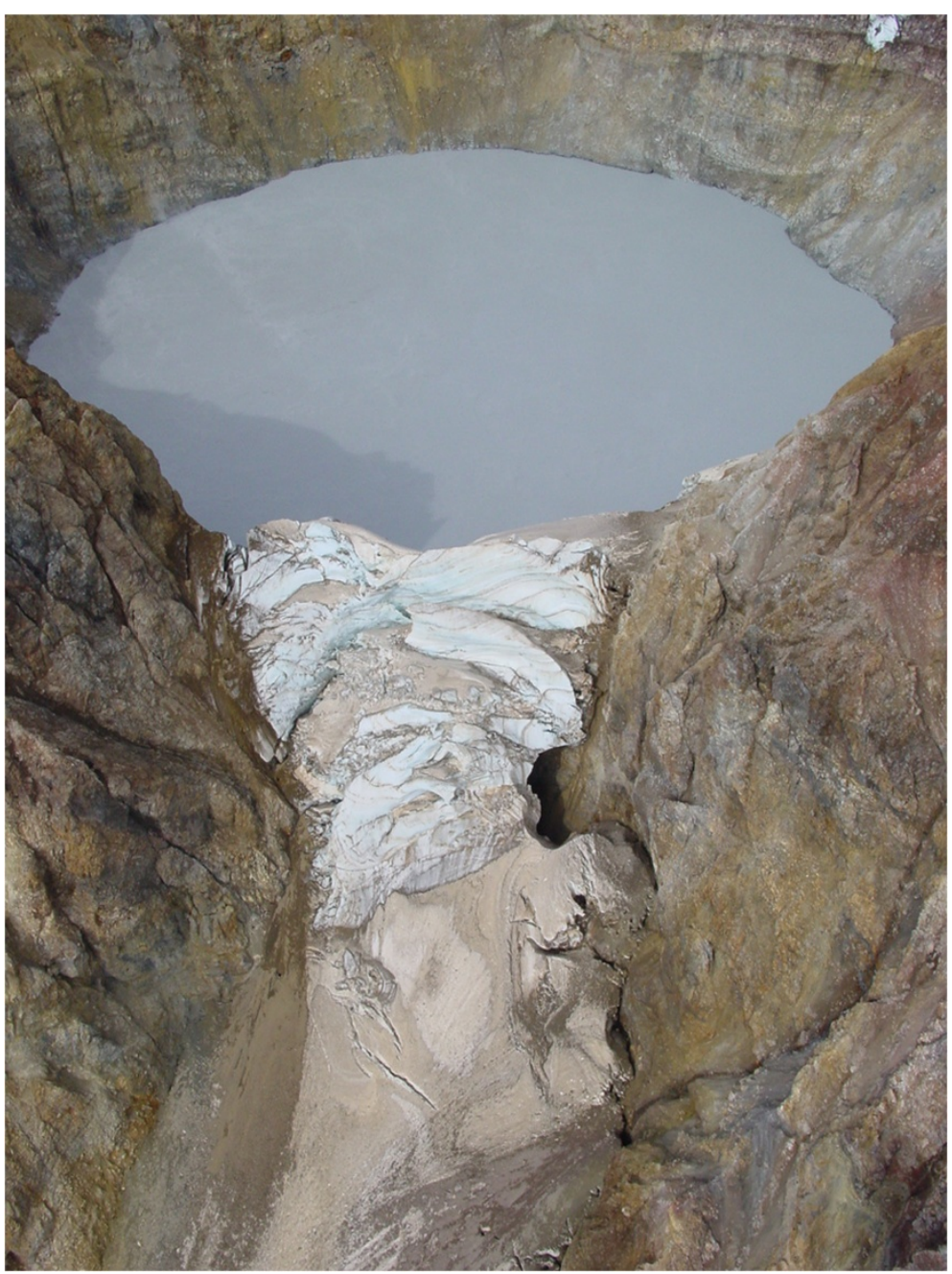

Figure 7 Picture of the natural "snow dam" blocking the newly formed Chiginagak crater lake, Alaska. Lake water drained at the base of the snow mass to generate a lahar/jökulhlaup downstream in early 2005 (Schaefer et al. 2008) (Picture by Game McGimsey, Alaska Volcano Observatory, US Geological Survey). 
Jökulhlaups can probably be forecast by tracking volume decrease in ice mass, or increased temperatures.

\section{Tsunamis and seiches}

A tsunami occurs when a large body of water is suddenly displaced from its equilibrium position, generating long waves which propagate with a low energy loss from deep to shallow waters, where they rapidly decrease in velocity and reach high amplitudes in coastal areas. Volcanorelated tsunamis can be associated with a variety of volcanic activities, such as submarine explosions in shallow waters, dense pyroclastic flows entering in the water and submarine mass movements. Within the context of the present study, these volcanic activities are often associated with magmatic unrest. Non-magmatic unrest phenomena are often slow and continuous, suggesting that nonmagmatic unrest manifestations (apart from phreatomagmatic and phreatic eruptions) are not advantageous for tsunami triggering, however, tsunamis can also be generated as a secondary effect of non-magmatic outcomes (e.g., mass failures and PDC). In general, tsunamis due to volcanic activity remain a poorly investigated field, with only a few recent studies (e.g., Maeno and Imamura 2007, 2011; Paris et al. 2014).

Seiches are standing waves mostly due to meteorological effects (e.g., atmospheric pressure variations), but also due to earthquakes or tsunamis. They may occur in closed or partially closed basins, as such, lake seiches are most common. Seiches form as waves move back and forth hitting lake basin walls (Ichinose et al. 2000). When a phreatic eruption disrupts a crater lake basin, waves concentrically move outwards from the centre of initial water mass displacement (Figure 5). The wave height of the seiches at the lake shore depends on the violence of the trigger, lake water volume, and basin morphology. Similarly, seiches have also been observed also in open sea bays, harbors and gulfs, where natural resonant oscillations are permitted by the basin geometry. Tsunami and seiches related to volcanic activity are very rare events, nonetheless their impact could be extremely high, depending on specific conditions of the event (e.g., dominant wavelength, period).

\section{Conclusions}

In this review paper we have attempted to categorize non-magmatic unrest, and have sought to describe indicators how to recognize non-magmatic unrest. With the aim to classify non-magmatic unrest features, we presented an event tree structure with a progressive level of detail along various tracks towards hazardous outcomes. This implies that, beyond the current classification, the non-magmatic unrest branch in the event tree could become the base for future probabilistic hazard assessment at any type of volcano, regardless of its state of unrest.
The role of gas and water (liquid or vapor) instead of magma as the driving agent for unrest is stressed. Many volcanoes experience a prolonged stage of hydrothermal unrest, which can alter the hydraulic and rock mechanical properties leading to destabilization of a volcanic edifice. Recognizing an increase in vapor pressure in hydrothermal systems may provide warning of phreatic eruptions. A sudden release of water from an aquifer or lake, or intense rainfall, can trigger lahars when these mobilize poorly consolidated volcanic deposits or altered sections of a volcano.

Hydrothermal unrest is the most obvious expression of non-magmatic unrest, which could eventually lead to hazardous outcomes. Tracking temporal variations in fluid migration, hydraulic pressure regimes, as well as variations in temperature and chemical compositions of fluids (gas and water) could help to forecast hazardous outcomes. This means that traditional monitoring schemes (seismicgeodetic-geochemical) should be expanded to include other monitoring methods that might reveal precursory signals of non-magmatic volcanic hazards.

Moreover, we do not know if many of the $\sim 1300$ poorly studied Holocene active volcanoes are in a state of non-magmatic unrest, and thus, as stressed by this study, could be potentially hazardous. Knowing whether a volcano is dormant, in a state of quiescence, or in a state of non-magmatic unrest is a first requisite for hazard forecasting. This basic principle could guide future monitoring strategies for those volcanoes that are potentially more hazardous than currently thought. We invite the scientific community to define and track the background behavior of many poorly studied, but potentially hazardous volcanoes in order to recognize, in a timely manner, a state that raises concern.

\section{Competing interests}

The authors declare that they have no competing interests.

\section{Authors' contributions}

DR guided the review process of the research, and is the main author of the manuscript. LS participated in the scientific discussions and drafted the manuscript. WM participated in the scientific discussions and drafted the manuscript. JG participated in the scientific discussions and drafted the manuscript. JS participated in the scientific discussions and drafted the manuscript. RT participated in the scientific discussions and drafted the manuscript. PP participated in the scientific discussions. All authors read and approved the final manuscript.

\section{Acknowledgments}

Chiara Montagna, Pablo Tierz, Raúl Mora-Amador, and Anita Grezio are thanked for fruitful discussions. This research was supported by funds from the EC Framework Program 7 under grant agreements \#282759: "VUELCO" and \#308665: "MEDSUV", and the Royal Society. We are grateful to Karoly Németh, Yuri Taran, Ana Belén Castro and AVO-USGS for providing pictures of the figures. Michael Manga and Nicolas Fournier are kindly acknowledged for their open-minded discussion during the review process. Jan Lindsay is thanked for swift editorial handling. 


\section{Author details}

${ }^{1}$ Istituto Nazionale di Geofisica e Vulcanologia, Sezione di Bologna, Bologna, Italy. ${ }^{2}$ Istituto Nazionale di Geofisica e Vulcanologia, Sezione di Roma 1, Rome, Italy. ${ }^{3}$ School of Earth Sciences, University of Bristol, Bristol, UK ${ }^{4}$ Istituto Nazionale di Geofisica e Vulcanologia, Sezione di Pisa, Pisa, Italy.

Received: 29 May 2014 Accepted: 20 November 2014 Published online: 06 December 2014

\section{References}

Aiuppa A, Federico C, Paonita A, Pecoraino G, Valenza M (2002) S, Cl and F degassing as an indicator of volcanic dynamics: The 2001 eruption of Mount Etna. Geophys Res Lett 29(11): doi:10.1029/2002GL015032

Aiuppa A, Federico C, Giudice G, Gurrieri S, Paonita A, Valenza M (2004) Plume chemistry provides insights into mechanisms of sulfur and halogen degassing in basaltic volcanoes. Earth Planet Sci Lett 222:469-483

Amoruso A, Crescentini L, Sabbetta I (2014) Paired deformation sources of the Campi Flegrei caldera (Italy) required by recent (1980-2010) deformation history. J Geophys Res 119:858-879, doi:10.1002/2013JB010392

Aspinall WP, Woo G, Voight B, Baxter PJ (2003) Evidence-based volcanology: application to eruption crises. J Volcanol Geotherm Res 128:273-285

Barberi F, Corrado A, Innocenti F, Luongo G (1984) Phlegrean Fields 1982-1984: Brief chronicle of a volcano emergency in a densely populated area. Bull Volcanol 47:175-185

Barberi F, Bertagnini A, Landi P, Principe C (1992) A review on phreatic eruptions and their precursors. J Volcanol Geotherm Res 52:231-246

Battaglia M, Vasco DW (2006) The search for magma reservoirs in Long Valley Caldera: Single versus distributed sources. Geol Soc Spec Publ 269:173-180

Battaglia M, Segall P, Roberts C (2003) The mechanics of unrest at Long Valley caldera, California 2. Constraining the nature of the source using geodetic and micro-gravity data. J Volcanol Geotherm Res 127(3-4):219245

Belousov A, Belousova M (2001) Eruptive process, effects and deposits of the 1996 and the ancient basaltic phreatomagmatic eruptions in Karymskoye lake, Kamchatka, Russia. In: White JDL, Riggs NR (eds) Volcaniclastic sedimentation in lacustrine settings. Blackwell Sciences, Oxford UK, pp 35-60

Bergfeld D, Evans WC, Howle JF, Farrar CD (2006) Carbon dioxide emissions from vegetation-kill zones around the resurgent dome of Long Valley caldera, eastern California, USA. J Volcanol Geotherm Res 152:140-156

Bergfeld D, Evans WC, Lowenstern JB, Hurwitz S (2012) Carbon dioxide and hydrogen sulfide degassing an cryptic thermal input to Brimstone Basin, Yellowstone National Park, Wyoming. Chem Geol 330-331:233-243, doi.org/ 10.1016/j.chemgeo.2012.09.001

Bianchi R, Corradini A, Federico C, Giberti G, Lanciano P, Pozzi JP, Sartoris G, Scandone R (1987) Modelling of surface ground deformation in volcanic areas: The 1970-1972 and 1982-1984 crises of Campi Flegrei, Italy. J Geophys Res 92(B13):14139-14150

Björnsson H (2002) Subglacial lakes and jökulhlaups in Iceland. Global Planet Change 35:255-271

Blong RJ (1984) Volcanic Hazards. Academic, Sydney, pp 42-47, 110-114,221-227

Bonafede M (1991) Hot fluid migration, an efficient source of ground deformation, application to the 1982-1985 crisis at Campi Flegrei-Italy. J Volcanol Geotherm Res 48:187-198

Bonafede M, Dragoni M, Quareni F (1986) Displacement and stress field produced by a centre of dilatation and by a pressure source in a visco-elastic half-space: Application to the study of ground deformation and seismic activity at Campi Flegrei, Italy. Geophys J R Astron Soc 87:455-485

Brodsky EE, Sturtevant B, Kanamori H (1998) Earthquakes, volcanoes and rectified diffusion. J Geophys Res 103(B10):23827-23838

Brown G, Rymer H, Dowden J, Kapadia P, Stevenson D, Barquero J, Morales LD (1989) Energy budget analysis for Poás Crater lake: implications for predicting volcanic activity. Nature 339:370-373

Browne PRL, Lawless JV (2001) Characteristics of hydrothermal eruptions, with examples from New Zealand and elsewhere. Earth Sci Rev 52:299-331

Capra L, Borselli L, Varley N, Gavilanes-Ruíz JC, Norini G, Sarocchi D, Caballero L, Cortés A (2010) Rainfall-triggered lahars at Volcán de Colima, Mexico: Surface hydro-repellency as initiation process. J Volcanol Geotherm Res 189:105-117, doi:10.1016/j.volgeores.2009010.014

Cardellini C, Chiodini G, Frondini F (2003) Application of stochastic simulation to $\mathrm{CO}_{2}$ flux from soil: mapping and quantification of gas release. J Geophys Res 108(B9):2425-2437
Casertano L, Olivieri del Castello L, Quagliariello MT (1976) Hydrodynamics and geodynamics in the Phlegrean Fields area of Italy. Nature 264:161-164

Chiodini G, Frondini F, Cardellini C, Granieri D, Marini L, Ventura G (2001) CO degassing and energy release at Solfatara volcano, Campi Flegrei, Italy. J Geophys Res 106(B8):16231-16221

Chiodini G, Todesco M, Caliro S, Del Gaudio C, Macedonio G, Russo M (2003) Magma degassing as a trigger of bradyseismic events: The case of Phlegrean Fields (Italy). Geophys Res Lett 30(8):1434, doi:10.1029/2002GL016790

Chiodini G, Caliro S, Lowenstern JB, Evans WC, Bergfeld D, Tassi F, Tedesco D (2012) Insights from fumaroles gas geochemistry on the origin of hydrothermal fluids on the Yellowstone Plateau. Geochim Cosmochim Acta 89:265-278, doi.org/10.1016/j.gca.2012.04.051

Christenson BW (2000) Geochemistry of fluids associated with the 1995-1996 eruption of Mt. Ruapehu, New Zealand: signatures and processes in the magmatic-hydrothermal system. J Volcanol Geotherm Res 97:1-30

Christenson BW, Werner CA, Reyes AG, Sherburn S, Scott BJ, Miller C, Rosenberg MJ, Hurst AW, Britten KA (2007) Hazards from hydrothermally sealed volcanic conduits. Eos 88(50):53-55

Christenson BW, Reyes AG, Young R, Moebis A, Sherburn S, Cole-Baker J, Britten K (2010) Cyclic processes and factors leading to phreatic eruption events: Insights from the 25 September 2007 eruption through Ruapehu Crater Lake, New Zealand. J Volcanol Geotherm Res 191:15-32

Cronin SJ, Neall VE, Lecointre JA, Palmer AS (1997) Changes in Whangaehu river lahar characteristics during the 1995 eruption sequence, Ruapehu volcano, New Zealand. J Volcanol Geotherm Res 76:47-61

D'Auria L, Giudicepietro F, Aquino I, Borriello G, Del Gaudio C, Lo Bascio D, Martini M, Ricciardi GP, Ricciolino P, Ricco C (2011) Repeated fluid-transfer episodes as a mechanism for the recent dynamics of Campi Flegrei caldera (1989-2010). J Geophys Res 116(B04313): doi:10.1029/2010JB007837

de Bélizal E, Lavigne F, Hadmoko DS, Degeai J-P, Dipayana GA, Mutaqin BW, Marfai MA, Coquet M, Le Mauff B, Robin A-K, Vidal C, Cholik N, Aisyah N (2013) Rain-triggered lahars following the 2010 eruption of Merapi volcano, Indonesia: A major risk. J Volcanol Geotherm Res 261:330-347, doi:10.1016/j.volgeores.2013.01.010

De Natale G, Pingue F, Allard P, Zollo A (1991) Geophysical and geochemical modeling of the 1982-1984 unrest phenomena at Campi Flegrei caldera (southern Italy). J Volcanol Geotherm Res 48:199-222

Delle Donne D, Harris AJL, Ripepe M, Wright R (2010) Earthquake-induced thermal anomalies at active volcanoes. Geology 38:771-774

Delmelle P, Bernard A (1994) Geochemistry, mineralogy, and chemical modeling of the acid crater lake of Kawah ljen volcano, Indonesia. Geochim Cosmochim Acta 58:2445-2460

Delmelle P, Bernard A (2000) Downstream composition changes of acidic volcanic waters discharged into the Banyupahit stream, ljen caldera, Indonesia. J Volcanol Geotherm Res 97:55-75

Delmelle P, Bernard A, Kusakabe M, Fischer TP, Takano B (2000) Geochemistry of the magmatic-hydrothermal system of Kawah ljen volcano, East Java, Indonesia. J Volcanol Geotherm Res 97:31-53

Delmelle P, Henley RW, Opfergelt S, Detienne M (2015) Summit acid crater lakes and flank instability in composite volcanoes. In: Rouwet D, Christenson BW, Tassi F, Vandemeulebrouck J (eds) Volcanic Lakes, Springer-Heidelberg., in press

Di Napoli R, Aiuppa A, Allard P (2013) First multi-gas based characterisation of the Boiling Lake volcanic gas (Dominica, Lesser Antilles). Ann Geophys 56(5):S0559, doi:10.4401/ag-6277

Dowden J, Kapadia P, Brown G, Rymer H (1991) Dynamics of a geyser eruption. J Geophys Res 96:18059-18071

Dvorak JJ, Mastrolorenzo G (1991) The mechanism of recent vertical crustal movements in Campi Flegrei caldera, Southern Italy. Geol Soc Am Special Paper:263

Dzurisin D, Yamashita KM (1987) Vertical surface displacement at Yellowstone caldera, Wyoming, 1976-986. J Geophys Res 92(B13):13753-13766

Eggert S, Walter TR (2009) Volcanic activity before and after large tectonic earthquakes: Observations and statistical significance. Tectonophys 471:14-26

Evans WC, Sorey ML, Cook AC, Kennedy BM, Shuster DL, Colvard EM, White LD, Huebner MA (2002) Tracing and quantifying magmatic carbon discharge in cold groundwaters: lessons learned from Mammoth Mountain, USA. J Volcanol Geotherm Res 114:291-312

Finizola A, Sortino F, Lénat J-F, Aubert M, Ripepe M, Valenza M (2003) The summit hydrothermal system of Stromboli. New insights from self-potential, temperature, $\mathrm{CO}_{2}$ and fumarolic fluid measurements, with structural and monitoring implications. Bull Volcanol 65:486-504, doi:10.1007/s00445-003-0276-z 
Fischer TP, Sturchio NC, Stix J, Arehart GB, Counce D, Williams SN (1997) The chemical and isotopic composition of fumarolic gases and spring discharges from Galeras Volcano, Colombia. J Volcanol Geotherm Res 77:229-253

Fournier N, Chardot L (2012) Understanding volcano hydrothermal unrest from geodetic observations: Insights from numerical modeling and application to White Island volcano, New Zealand. J Geophys Res 117, B11208, doi:10.1029/2012JB009469

Fournier N, Jolly A (2014) Detecting complex eruption sequence and directionality from high-rate geodetic observations: The August 6, 2012 Te Maari eruption. New Zealand. J Volcanol Geotherm Res, Tongariro. doi:10.1016/j.jvolgeores.2014.05.021

Fournier N, Witham F, Moureau-Fournier M, Bardou L (2009) Boiling Lake of Dominica, West Indies: High-temperature volcanic crater lake dynamics. J Geophys Res 114(B02203): doi:10.1029/2008JB005773

Gaeta FS, De Natale G, Peluso F, Mastrolorenzo G, Castagnolo D, Troise C, Pingue F, Mita D, Rossano G (1998) Genesis and evolution of unrest episodes at Campi Flegrei caldera: the role of thermal-fluid-dynamical processes in the geothermal system. J Geophys Res 103(B9):20921-20933

Gehring AU, Schosseler PM, Weidler PG (1999) Mineral formation and redox sensitive trace elements in a near-surface hydrothermal alteration system. Geochim Cosmochim Acta 63(13/14):2061-2069

Getahun A, Reed MH, Symonds R (1996) Mount St. Augustine volcano fumaroles wall rock alteration: mineraology, zoning, composition and numerical models of its formation process. J Volcanol Geotherm Res 71:73-107

Giggenbach WF, Corrales Soto R (1992) Isotopic and chemical composition of water and steam discharges from volcanic-magmatic-hydrothermal systems of Guanacaste Geothermal Province, Costa Rica. Appl Geochem 7:309-332

Giggenbach WF, García PN, Londoño CA, Rodríguez VL, Rojas GN, Calvache VML (1990) The chemistry of fumarolic vapor and thermal-spring discharges from the Nevado del Ruíz volcano-magmatic-hydrothermal system, Colombia. J Volcanol Geotherm Res 42:13-39

Gottsmann J, Folch A, Rymer H (2006) Unrest at Campi Flegrei: A contribution to the magmatic versus hydrothermal debate from inverse and finite element modeling. J Geophys Res 111(B07203): doi:10.1029/2005JB003745

Gottsmann J, Carniel R, Coppo N, Wooller L, Hautmann S, Rymer H (2007) Oscilations in hydrothermal systems as a source of periodic unrest at caldera volcanoes: Multiparameter insights from Nysiros, Greece. Geophys Res Lett 34(L07307), doi:10.1029/2007GL029594

Hall M, Mothes P, Samaniego P, Yepes H, Andrade D (2004) Mapa regional de los peligros volcánicos potenciales del volcán Cotopaxi, Zona Sur. 1:50,000. Instituto Geofísica, Escuela Politecnica Nacional, Quito

Harris A, Carniel R, Patrick M, Dehn J (2004) The sulfur flow fields of the Fossa di Vulcano. Bull Volcanol 66(8):749-759

Healy J, Lloyd EF, Banwell CJ, Adams RD (1965) Volcanic eruption on Raoul Island, November 1964. Nature 205:743-745

Hill DP (2008) Dynamic stresses, Coulomb failure, and remote triggering. Phys Today 55(11):41-47

Hurst AW, McGinty PJ (1999) Earthquake swarms to the west of Mt Ruapehu preceding its 1995 eruption. J Volcanol Geotherm Res 90:19-28

Hurwitz S, Ingebritsen SE, Sorey ML (2002) Episodic thermal perturbations associated with groundwater flow: An example from Kilauea Volcano, Hawaii. J Geophys Res 107(B11):2297, doi:10.1029/2001JB001654

Hurwitz S, Goff F, Janik CJ, Evans WC, Counce DA, Sorey ML, Ingebritsen SE (2003) Mixing of magmatic volatiles with groundwater and interaction with basalt on the summit of Kilauea Volcano, Hawaii. J Geophys Res 108 (B1):2028, doi:10.1029/2001JB001594

Ichihara M, Brodsky EE (2006) A limit on the effect of rectified diffusion in volcanic systems. Geophys Res Lett 33(L02316): doi:10.1029/2005GL024753

Ichinose GA, Anderson JA, Satake K, Schweichert RA, Laharen MM (2000) The potential hazard from tsunami and seiche waves generated by large earthquakes within Lake Tahoe, California-Nevada. Geophys Res Lett 27(8):1203-1206

Ingebritsen SE, Rojstaczer SA (1993) Controls on geyser periodicity. Science 262:889-892

Ingebritsen SE, Rojstaczer SA (1996) Geyser periodicity and the response of geysers to deformation. J Geophys Res 101:21891-21905

Ingebritsen SE, Galloway DL, Colvard EM, Sorey ML, Mariner RH (2001) Time-variation of hydrothermal discharge at selected sites in the western United States: implications for monitoring. J Volcanol Geotherm Res 111:1-23

Inguaggiato S, Mazot A, Diliberto IS, Inguaggiato C, Madonia P, Rouwet D, Vita F (2012) Total $\mathrm{CO}_{2}$ output from Vulcano Island (Aeolian Islands, Italy). Geochem Geophys Geosyst 13(2), Q022012, doi:10.1029/2011GC003920
Jolly AD, Sherburn S, Jousset P, Kilgour G (2010) Eruption source processes derived from seismic and acoustic observations of the 25 September 2007 Ruapehu eruption, North Island, New Zealand. J Volcanol Geotherm Res 191:33-45

Jolly AD, Jousset P, Lyons JJ, Carniel R, Fournier N, Fry B, Miller C (2014) Seismo-acoustic evidence for an avalanche driven phreatic eruptions through a beheaded hydrothermal system: An example from the 2012 Tongariro eruption. J Volcanol Geotherm Res, doi:10.1016/j.jvolgeores.2014.04.007

Joseph EP, Fournier N, Lindsay JM, Fischer TP (2011) Gas and water geochemistry of geothermal systems in Dominica, Lesser Antilles island arc. J Volcano Geotherm Res 206:1-14, doi:10.1016/j.jvolgeores.2011.06.007

Joseph EP, Fournier N, Lindsay JM, Robertson R, Beckles DM (2013) Chemical and isotopic characteristics of geothermal fluids from Sulphur Springs, Saint Lucia. J Volcanol Geotherm Res 254:23-36, doi.org/10.1016/j.jvolgeores.2012.12.013

Kazahaya K, Shinohara H, Saito G (1994) Excessive degassing of Izu-Oshima volcano: magma convection in a conduit. Bull Volcanol 56:207-216

Kempter KA, Rowe GL (2000) Leakage of Active Crater lake brine through the north flank at Rincón de la Vieja volcano, northwest Costa Rica, and implications for crater collapse. J Volcanol Geotherm Res 97:143-159

Kerle N, van Wijck de Vries B (2001) The 1998 debris avalanche at Casita volcano, Nicaragua-Investigation of structural deformation as the cause of slope instability using remote sensing. J Volcanol Geotherm Res 105:49-63

Kieffer SW (1984) Seismicity at Old Faithful geyser: an isolated source of geothermal noise and possible analogue of volcanic seismicity. J Volcanol Geotherm Res 22:59-95

Kilgour G, Manville V, Della Pasqua F, Reyes AG, Graettinger AH, Hodgson KA, Jolly AD (2010) The 25 September 2007 eruption of Mt. Ruapehu, New Zealand: directed ballistics, Surtseyan jets, and ice-slurry lahars. J Volcanol Geotherm Res 191:1-14

Kling GW, Clark MA, Compton HR, Devine JD, Evans WC, Humphrey AM, Koenigsberg EJ, Lockwood JP, Tuttle ML, Wagner GN (1987) The 1986 Lake Nyos gas disaster in Cameroon, West Africa. Science 236:169-175

Kokelaar BP (1983) The mechanism of Surtseyan volcanism. J Geol Soc London 140:939-994

Kokelaar BP, Durant GP (1983) The submarine eruption of Surtla (Surtsey, Iceland). J Volcanol Geotherm Res 19:239-246

Kusakabe M (2015) Evolution of $\mathrm{CO}_{2}$ content in Lakes Nyos and Monoun, and sub-lacustrine $\mathrm{CO}_{2}$-recharge system at Lake Nyos as envisaged from $\mathrm{C} /{ }^{3} \mathrm{He}$ ratios in noble gas signatures. In: Eds Rouwet D, Christenson BW, Tassi F, Vandemeulebrouck J (eds) Volcanic Lakes, Springer-Heidelberg., In press

Lewicki JL, Hilley GE (2014) Multi-scale observations of the variability of magmatic $\mathrm{CO}_{2}$ emissions, Mammoth Mountain, CA, USA. J Volcanol Geotherm Res 284:1-15, doi:10.1016/j.jvolgeores.2014.07.011

Lewicki JL, Fischer TP, Williams SN (2000) Chemical and isotopic compositions of fluids at Cumbal Volcano, Colombia: evidence for magmatic contribution. Bull Volcanol 62:347-36

Lewicki JL, Hilley GE, Tosha T, Aoyagi R, Yamamoto K, Benson SM (2007a) Dynamic coupling of volcanic $\mathrm{CO}_{2}$ flow and wind at the Horseshoe Lake tree kill, Mammoth Mountain, California. Geophys Res Lett 34(L03401): doi:10.1029/2006GL028848

Lewicki JL, Oldenburg CM, Dobeck L, Spangler L (2007b) Surface $\mathrm{CO}_{2}$ leakage during two shallow subsurface $\mathrm{CO}_{2}$ releases. Geophys Res Lett 34, L24402, doi:10.1029/2007GL032047

Linde AT, Sacks IS, Johnston MU, Hill DP, Bilham RG (1994) Increased pressure from rising bubbles as a mechanism for remotely triggered seismicity. Nature 371:408-410

Löhr AJ, Bogaard TA, Heikens A, Hendriks MR, Sumarti S, van Bergen MJ, Van Gestel CAM, Van Straalen NM, Vroon PZ, Widianarko B (2005) Natural pollution caused by the extremely acidic crater lake Kawah ljen, East Java, Indonesia. Environ Sci Pollut Res 12(2):89-95

López DL, Williams SN (1993) Catastrophic volcanic collapse: relation to hydrothermal processes. Science 260:1794-1796

Lowenstern JB, Hurwitz S (2008) Monitoring a supervolcano in repose; heat and volatile flux at the Yellowstone Caldera. Elements 4:35-40

Lowenstern JB, Evans WC, Bergfeld D, Hunt AG (2014) Prodigious degassing of a billion years of accumulated radiogenic helium at Yellowstone. Nature 506:355-358, doi:10.1038/nature12992

Maeno F, Imamura F (2007) Numerical investigations of tsunamis generated by pyroclastic flows from the Kikai caldera, Japan. Geophys Res Lett 34(L23303): doi:10.1029/2007GL031222

Maeno F, Imamura F (2011) Tsunami generation by a rapid entrance of pyroclastic flow into the sea during the 1883 Krakatau eruption, Indonesia. J Geophys Res 116(B09205): doi:10.1029/2011JB008253 
Manga M, Brodsky E (2006) Seismic triggering of eruptions in the far field: volcanoes and geysers. Annu Rev Earth Planet Sci 34:263-291

Manville V, Németh K, Kano K (2009) Source to sink: a review of three decades of progress in the understanding of volcaniclastic processes, deposits, and hazards. Sediment Geol 220:136-161

Martin RS, Sawyer GM, Spampinato L, Salerno GG, Ramírez C, Ilyinskaya E, Witt MLI, Mather TA, Watson IM, Phillips JC, Oppenheimer C (2010) A total volatile inventory for Masaya Volcano, Nicaragua. J Geophys Res 115(B09215): doi:10.1029/2010JB007480

Marzocchi W (2002) Remote seismic influence on large explosive eruptions. J Geophys Res 107(B1):2018, doi:10.1029/2001JB000307

Marzocchi W, Bebbington M (2012) Probabilistic eruption forecasting at short and long time scales. Bull Volcanol, doi:10.1007/s00445-012-0633-x

Marzocchi W, Casarotti E, Piersanti A (2002) Modeling the stress variations induced by great earthquakes on the largest volcanic eruptions of the $20^{\text {th }}$ century. J Geophys Res 107(B1 1):2320, doi:10.1029/2001JB001391

Marzocchi W, Sandri L, Gasparini P, Newhall C, Boschi E (2004a) Quantifying probabilities of volcanic events: the example of volcanic hazard at Mt Vesuvius. J Geophys Res 109(B11201)

Marzocchi W, Zaccarelli L, Boschi E (2004b) Phenomenological evidence if favor of a remote seismic coupling for large volcanic eruptions. Geophys Res Lett 31(L04601)

Marzocchi W, Sandri L, Selva J (2008) BET_EF: a probabilistic tool for long- and short-term eruption forecasting. Bull Volcanol 70:623-632

Marzocchi W, Sandri L, Selva J (2010) BET_VH: a probabilistic tool for long-term volcanic hazard assessment. Bull Volcanol 72:705-716

Mastin L (1991) The roles of magma and groundwater in the phreatic eruptions at Inyo Craters, Long Valley Caldera, California. Bull Volcanol 53:579-596

Mastin LG (1995) Thermodynamics of gas and steam-blast eruptions. Bull Volcanol 57:85-98

Mastin LG, Witter JB (2000) The hazards of eruptions through lakes and seawater. J Volcanol Geotherm Res 97:195-214

Mazot A, Rouwet D, Taran Y, Inguaggiato S, Varley N (2011) $\mathrm{CO}_{2}$ and $\mathrm{He}$ degassing at El Chichón volcano, Chiapas, Mexico: gas flux, origin and relationship with local and regional tectonics. Bull Volcanol 73:423-441

Menyailov IA, Nikitina LP, Shapar VN, Pilipenko VP (1986) Temperature increase and chemical change of fumarolic gases at Momotombo volcano, Nicaragua, in 1982-1985: are these indicators of a possible eruption? J Geophys Res 91 (B12):1219912214

Moore JG, Nakamura K, Alcaraz A (1966) The 1965 eruption of Taal Volcano. Science 7:955-960

Mothes P, Hall M, Andrade D, Samaniego P, Pierson TC, Gorki RA, Yepes H (2004) Character, stratigraphy and magnitude of historical lahars of Cotopaxi volcano (Ecuador). Acta Vulcanol 1(2):1-23

Nairn IA, Wood CP, Hewson CAY (1979) Phreatic eruptions of Ruapehu: April 1975. NZ J Geol Geophys 22:155-173

Naranjo JA (1985) Sulphur flows at Lastarria volcano in the North Chilean Andes. Nature 313:778-780

Németh K, Cronin SJ, Charley D, Harrison M, Garae E (2006) Exploding lakes in Vanuatu - Surtseyan-style eruptions witnessed on Ambae Island. Episodes 29:87-92

Neumann van Padang M (1960) Measures taken by the authorities of the volcanological survey to safeguard the population from the consequences of volcanic outbursts. Bull Volcanol 23:181-192

Newhall CG, Dzurisin D (1988) Historical unrest at large calderas of the world. US Geol Surv Bull 1855:1108

Newhall C, Hoblitt R (2002) Constructing event trees for volcanic crises. Bull Volcanol 64:3-20

Ohba T, Hirabayashi J, Nogami K (2008) Temporal changes in the chemistry of lake water within Yugama Crater, Kusatsu-Shirane Volcano, Japan: Implications for the evolution of the magmatic-hydrothermal system. J Volcanol Geotherm Res 178:131-144

Oppenheimer C (1992) Sulphur eruptions at Volcán Poás, Costa Rica. J Volcanol Geotherm Res 49:1-21

Oppenheimer C (2011) Eruptions that shook the world. Cambridge University Press, Cambridge University Press, p 392. ISBN 978-0-521-64112-8

Oppenheimer C, Stevenson D (1989) Liquid sulphur lakes at Poás volcano. Nature 32:790-793

Orsi G, Civetta L, Del Gaudio C, de Vita S, di Vito MA, Isaia R, Petrazzuoli S, Ricciardi G, Ricco C (1999) Short-term ground deformations and seismicity in the nested Campi Flegrei caldera (Italy): an example of active block-resurgence in a densely populated area. J Volcanol Geotherm Res 91(2-4):415-451

Paris R, Switzer AD, Belousova M, Belousov A, Ontowirjo B, Whelley PL, Ulvrova M (2014) Volcanic tsunami: a review of source mechanisms, past events and hazards in Southeast Asia (Indonesia, Philippines, Papua New Guinea). Nat Haz 70(1):447-470

Pasternack GB, Varekamp JC (1994) The geochemistry of the Keli Mutu crater lake, Flores, Indonesia. Geochem J 28:243-262

Pasternack GB, Varekamp JC (1997) Volcanic lake systematcis 1. Physical constraints. Bull Volcanol 58:528-538

Pavanelli N (2006) La pericolosità del Vulcano Irazú (Costa Rica): dall'attività eruttiva ai movimenti di massa. PhD Thesis. Dep of Earth Sci, University of Florence, Florence, Italy

Phillipson G, Sobradelo R, Gottsmann J (2013) Global volcanic unrest in the 21st century: An analysis of the first decade. J Volcanol Geotherm Res 264:183-196

Pierson TC, Janda RJ, Thouret JC, Borrero CA (1990) Perturbation and melting of snow and ice by the 13 November 1985 eruption of Nevado del Ruíz, Colombia, and consequence mobilization, flow and deposition of lahars. J Volcanol Geotherm Res 41:17-66

Pierson TC, Janda RJ, Umbal JV, Daag AS (1992) Immediate and long-term hazards from lahars and excess sedimentation in rivers draining Mt. Pinatubo, Philippines. ASGS Water-Resources Investigations Report 92-4039

Pistolesi M, Cioni R, Rosi M, Cashman KV, Rossotti A, Aguilera E (2013) Evidence for lahar-triggering mechanisms in complex stratigraphic sequences: the post-XII century eruptive activity of Cotopaxi Volcano, Ecuador. Bull Volcanol 75:698, doi:10.1007/s00445-013-0698-1

Pistolesi M, Cioni R, Rosi M, Aguilera E (2014) Lahar hazard assessment in the southern drainage system of Cotopaxi volcano, Ecuador: Results from multiscale lahar simulations. Geomorphology 207:51-63, doi:10.1016/j. geomorph.2013.10.026

Potter SH (2014) Communicating the status of volcanic activity in New Zealand, with specific application to caldera unrest. PhD thesis. Massey University, Wellington, New Zealand, p 409

Ramírez CJ, Mora-Amador RA, González G, Alpizar Y (2013) Applications of infrared cameras at Costa Rican volcanoes, crater lakes and thermal features. $8^{\text {th }}$ Workshop on Volcanic Lakes, IAVCEI Commission on Volcanic Lakes, Japan, 6

Reid ME (2004) Massive collapse of volcanic edifices triggered by hydrothermal pressurization. Geology 32:373-376

Révil A, Finizola A, Sortino F, Ripepe M (2004) Geophysical investigations at Stromboli volcano, Italy: implications for ground water flow and paroxysmal activity. Geophys J Int 157:426-440, doi:10.1111/j.1365-246X.2004.02181.X

Rodolfo K, Unbal J, Alonso R, Remotigue M, Paladio M, Salvador J, Evangelista D, Miller Y (1996) Two years of lahars on the western flank of Mount Pinatubo, Philippines: initation, flow processes, deposits, and attendant geomorphic and hydraulic changes. In: Newhall C, Punongbayan R (eds) Fire and mud: eruptions and lahars of Mount Pinatubo. Philippine Institute of Volcanology and Seismology, Quezon City, And University of Washington Press (Seattle)., pp 989-1013

Rouwet D, Morrissey MM (2015) Mechanisms of crater lake breaching eruptions. In: Rouwet D, Christenson BW, Tassi F, Vandemeulebrouck J (eds) Volcanic Lakes, Springer-Heidelberg., in press

Rouwet D, Taran Y, Varley NR (2004) Dynamics and mass balance of El Chichón crater lake, Mexico. Geofis Int 43:427-434

Rouwet D, Taran Y, Inguaggiato S, Varley N, Santiago SJA (2008) Hydrochemical dynamics of the "lake-spring" system in the crater of El Chichón volcano (Chiapas, Mexico). J Volcanol Geotherm Res 178:237-248

Rouwet D, Inguaggiato S, Taran Y, Varley N, Santiago Santiago JA (2009) Chemical and isotopic compositions of thermal springs, fumaroles and bubbling gases at Tacaná Volcano (Mexico-Guatemala): implications for volcanic surveillance. Bull Volcanol 71:319-335, doi:10.1007/s00445-008-0226-x

Rouwet D, Taran Y, Inguaggiato S (2015) Fluid geochemistry of Tacaná volcanohydrothermal system. In: Scolamacchia T, Macías JL (eds) Active volcanoes of the world, Springer-IAVCEI., in press

Rouwet D, Tassi F, Mora-Amador R, Sandri L, Chiarini V (2014) Past, present and future of volcanic lake monitoring. J Volcanol Geotherm Res 272:78-97, doi:10.1016/j.jvolgeores.2013.12.009

Rowe GL, Brantley SL, Fernández JF, Borgia A (1995) The chemical and hydrologic structure of Poás Volcano, Costa Rica. J Volcanol Geotherm Res 64:233-267

Rymer H, Locke CA, Borgia A, Martínez M, Brenes J, Van der Laat R, Williams-Jones G (2009) Long-term fluctuations in volcanic activity: implications for future environmental impact. Terra Nova 21:304-309 
Salaün A, Villemant B, Gérard M, Komorowski J-C, Michel A (2011) Hydrothermal alteration in andesitic Volcanoes: Trace element redistribution in active and ancient hydrothermal systems of Guadeloupe (Lesser Antilles). J Geochem Expl 111:59-83

Sandri L, Guidoboni E, Marzocchi W, Selva J (2009) Bayesian Event Tree (BET) for eruption forecasting at Vesuvius, Italy: a retrospective forward application to 1631 eruption. Bull Volcanol 71:729-745

Sandri L, Jolly G, Lindsay J, Howe T, Marzocchi W (2012) Combining long- and short-term probabilistic volcanic hazard assessment with cost-benefit analysis to support decision making in a volcanic crisis from the Auckland Volcanic Field, New Zealand. Bull Volcanol 74(3):705-723, doi:10.1007/s00445-011-0556-y

Sandri L, Thouret J-C, Constantinescu R, Biass S, Tonini R (2014) Long-term multi-hazard assessment for El Misti volcano (Peru). Bull Volcanol 76:771, doi:10.1007/s00445-013-0771-9

Schaefer JR, Scott WE, Evans WC, Jorgenson J, McGimsey RG, Wang B (2008) The 2005 catastrophic acid crater lake drainage, lahar, and acidic aerosol formation at Mount Chiginagak volcano, Alaska, USA: field observations and preliminary water and vegetation chemistry results. Geochem Geophys Geosyst 9(7): doi:10.1029/2007GC001900

Scott KM (1988) Origins, behavior, and sedimentology of lahars and lahar-runout flows in the Toutle-Cowlitz system. USGS Prof Pap 1447-A:1-74

Selva J, Costa A, Marzocchi W, Sandri L (2010) BET_VH: exploring the influence of natural uncertainties on long-term hazard from tephra fallout at Campi Flegrei (Italy). Bull Volcanol 72:717-733

Selva J, Marzocchi W, Papale P, Sandri L (2012) Operational eruption forecasting at high-risk volcanoes: the case of Campi Flegrei, Naples. J Appl Volcanol 1:5, http://www.appliedvolc.com/content/1/1/5

Shepherd JB, Sigurdsson H (1982) Mechanism of the 1979 explosive eruption of Soufrière volcano, St Vincent. J Volcanol Geotherm Res 13:119-130

Shepherd JB, Aspinall WP, Rowley K, Pereira J, Sigurdsson H, Fiske R, Tomblin J (1979) The eruption of Soufrière volcano, St Vincent, April-June 1979. Nature 282(5734):24-28

Shinohara H, Giggenbach WF, Kazahaya K, Hedenquist JW (1993) Geochemistry of volcanic gases and hot springs of Satsuma-Iwojima, Japan: Following Matsuo. Geochem J 27:271-285

Shinohara H, Kazahaya K, Saito G, Mastushima N, Kawanabe Y (2002) Degassing activity from Iwodake rhyolitic cone, Satsuma-Iwojima volcano, Japan: Formation of a new degassing vent, 1990-1999. Earth Planets Space 54:175-185

Sobradelo R, Bartolini S, Martí J (2014) HASSET: a probability event tree tool to evaluate future volcanic scenarios using Bayesian inference. Bull Volcanol 76:770, doi:10.1007/s00445-013-0770-x

Sparks RSJ (2003) Forecasting volcanic eruptions. Earth Plan Sci Lett 210:1-15

Sriwana T, Van Bergen MJ, Sumarti S, de Hoog JCM, van Os BJH, Wahyuningsih R, Dam MAC (1998) Volcanogenic pollution by acid water discharges along Ciwidey River, West Java (Indonesia). J Geochem Explor 62:161-182

Stimac JA, Goff F, Counce D, Larocque ACL, Hilton DR, Morgenstern U (2004) The crater lake and hydrothermal system of Mount Pinatubo, Philippines: evolution in the decade after eruption. Bull Volcanol 66:149-167

Sturchio NC, Williams SN (1990) Variations in chemistry of acid-sulfate-chloride springs at Nevado del Ruíz volcano, Colombia: November 1985 through December 1988. J Volcanol Geotherm Res 42:203-210

Sturchio NC, Williams SN, Sano Y (1993) The hydrothermal system of Volcán Puracé, Colombia. Bull Volcanol 55:289-296

Takano B, Saitoh H, Takano E (1994) Geochemical implications of subaqueous molten sulfur at Yugama crater lake, Kusatsu-Shirane volcano, Japan. Geochem J 28:199-216

Taran YA, Peiffer L (2009) Hydrology, hydrochemistry and geothermal potential of El Chichón volcano-hydrothermal system, Mexico. Geothermics 38:370-378

Taran Y, Rouwet D (2008) Estimating thermal inflow to El Chichón crater lake using the energy-budget, chemical and isotope balance approaches. J Volcanol Geotherm Res 175:472-481

Taran YA, Hedenquist JW, Korzhinsky MA, Tkachenko SI, Shmulovich KI (1995) Geochemistry of magmatic gases from Kudryavy volcano, Iturup, Kuril Islands. Geochim Cosmochim Acta 59:1749-1761

Taran Y, Fischer TP, Pokrovsky B, Sano Y, Armienta MA, Macías JL (1998) Geochemistry of the volcano-hydrothermal system of El Chichón Volcano, Chiapas, Mexico. Bull Volcanol 59:436-449

Taran Y, Rouwet D, Inguaggiato S, Aiuppa A (2008) Major and trace element geochemistry of neutral and acidic thermal springs at El Chichón volcano.
Mexico Implications for monitoring of the volcanic activity. J Volcanol Geotherm Res 178:224-236, doi:10.1016/j.jvolgeores.2008.06.030

Tassi F, Rouwet D (2014) An overview of the structure, hazards, and methods of investigation of Nyos-type lakes from the geochemical perspective. J Limno 73(1):39-54, doi:10.4081/jlimnol.2014.836

Thorarinsson S (1967) Surtsey: the new Island in the North Atlantic. Viking, NY. $\mathrm{pp}, 47$

Thouret JC, Abdurachman KE, Bourdier JL, Bronto S (1998) Origin, characteristics, and behavior of lahars following the 1990 eruption of Kelud volcano, eastern Java (Indonesia). Bull Volcanol 59:460-480

Todesco M, Berrino G (2005) Modeling hydrothermal fluid circulation and gravity signals at the Phlegraean Fields caldera. Earth Planet Sci Lett 240:328-338

Todesco M, Chiodini G, Macedonio G (2003) Monitoring and modelling hydrothermal fluid emission at La Solfatara (Phlegrean Fields, Italy). An interdisciplinary approach to the study of diffuse degassing. J Volcanol Geotherm Res 125:57-79

Vallance JW (2000) Lahars. In: Sigurdsson H (ed) Encyclopedia of Volcanoes. Academic, United States, pp 601-616

van Hinsberg V, Berlo K, Sumarti S, van Bergen M, Williams-Jones A (2010) Extreme alteration by hyperacidic brines at Kawah ljen volcano, East Java, Indonesia: II Metasomatic imprint and element fluxes. J Volcanol Geotherm Res 196:169-184, doi:10.1016/j.jvolgeores.2010.07.004

van Manen SM (2014) Hazard and risk perception at Turrialba volcano (Costa Rica) implications for disaster risk management. Appl Geograph 50:63-73, doi.org/10.1016/j.apgeog.2014.02.004

van Rotterdam-Los AMD, Vriend SP, van Bergen MJ, van Gaans PFM (2008) The effect of naturally acidified irrigation water on agricultural volcanic soils. The case of Asembagis, Java, Indonesia. J Geochem Explor 96:53-68

Vandemeulebrouck J, Stemmelen D, Hurst T, Grangeon J (2005) Analogue modeling of instabilities in crater lake hydrothermal systems. J Geophys Res 110(B02212): doi:10.1029/2003JB002794

Varekamp JC, Ouimette AP, Herman SW, Bermúdez A, Delpino D (2001) Hydrothermal element fluxes from Copahue, Argentina: A "beehive" volcano in turmoil. Geology 29:1059-1062

Villasante-Marcos V, Finizola A, Abella R, Barde-Cabusson S, Blanco MJ, Brenes B, Cabrera V, Casas B, De Agustín P, Di Gangi F, Domínguez I, García O, Gomis A, Guzmán J, Iribarren I, Levieux G, López C, Luengo-Oroz N, Martín I, Moreno M, Meletlidis S, Morin J, Moure D, Pereda J, Ricci T, Romero E, Schütze C, Suski-Ricci B, Torres P, Trigo P (2014) Hydrothermal system of Central Tenerife Volcanic Complex, Canary Islands (Spain), inferred from self-potential measurements. J Volcanol Geotherm Res 272:59-77, doi:10.1016/j.jvolgeores.2013.12.007

Voight B, Janda RJ, Glicken H, Douglass PM (1983) Nature and mechanics of the Mount St. Helens rockslide-avalanche of 18 May 1980. Geotechnique 33:243-273

Walter TR, Amelung F (2007) Volcanic eruptions following $M \geq 9$ megathrust earthquakes: Implications for the Sumatra-Andaman volcanoes. Geol 35:539-542

Watt SFL, Pyle DM, Mather TA (2009) The influence of great earthquakes on volcanic eruption rate along the Chilean subduction zone. Earth Planet Sci Lett 277:399-407, doi:10.1016/j.epsl.2008.11.005

Werner C, Brantley S (2003) $\mathrm{CO}_{2}$ emissions from the Yellowstone volcanic system. Geochem Geophys Geosyst 4(7): doi.org/10.1029/2002GC000473

Werner C, Cardellini C (2006) Comparison of carbon dioxide emissions with fluid upflow, chemistry, and geologic structures at the Rotorua geothermal system, New Zealand. Geothermics 35:221-238, doi:10.1016/j.geothermics.2006.02.006

Werner C, Chiodini G, Voigt D, Caliro S, Avino R, Russo M, Brombach T, Wyngaard J, Brantley S (2003) Monitoring volcanic hazard using eddy covariance at Solfatare volcano, Naples, Italy. Earth Planet Sci Lett 210:561-577, doi:10.1016/S0012-821X(03)00127-4

Werner C, Hurwitz S, Evans WC, Lowenstern JB, Bergfeld D, Heasler H, Jaworowski C, Hunt A (2008) Volatile emissions and gas geochemistry of Hot Spring Basin, Yellowstone National Park, USA. J Volcanol Geotherm Res 178:751-762

White DE (1967) Some principles of geyser activity, mainly from Steamboat Springs, Nevada. Am J Sci 265:641-684

Williams-Jones G, Rymer H, Rothery DA (2003) Gravity changes and passive $\mathrm{SO}_{2}$ degassing at the Masaya caldera complex, Nicaragua. J Volcanol Geotherm Res 123:137-160

Zen MT, Hadikusumo D (1965) The future danger of Mt. Kelut (Eastern Java-Indonesia). Bull Volcanol 28:275-282 
Zimmer M, Erzinger J (2003) Continuous $\mathrm{H}_{2} \mathrm{O}, \mathrm{CO}_{2},{ }^{222} \mathrm{Rn}$ and temperature measurements on Merapi Volcano, Indonesia. J Volcanol Geotherm Res 125:25-38

Zlotnicki J, Vargemezis G, Mille A, Bruère F, Hammouya G (2006) State of the hydrothermal activity of Soufrière of Guadeloupe volcano inferred by VLF surveys. J Appl Geophys 58:265-279, doi:10.1016/j.jappgeo.2005.05.004

doi:10.1186/s13617-014-0017-3

Cite this article as: Rouwet et al:: Recognizing and tracking volcanic hazards related to non-magmatic unrest: a review. Journal of Applied Volcanology 2014 3:17.

Submit your manuscript to a SpringerOpen ${ }^{\circ}$ journal and benefit from:

- Convenient online submission

- Rigorous peer review

- Immediate publication on acceptance

- Open access: articles freely available online

- High visibility within the field

- Retaining the copyright to your article

Submit your next manuscript at $\boldsymbol{\nabla}$ springeropen.com 